This is a pre-copyedited, author-produced PDF version following peer review of the article: DelgadoArtés, R., V. Garófano-Gómez, J. V. Oliver-Villanueva, E. Rojas-Briales. 2022. Land use/cover change analysis in the Mediterranean region: a regional case study of forest evolution in Castelló (Spain) over 50 years. Land Use Policy, 114, 105967. DOI: 10.1016/j.landusepol.2021.105967, which has been published in the definitive publisher-authenticated form at: https://www.sciencedirect.com/science/article/pii/S0264837721006906 Article accepted on December 22 ${ }^{\text {nd }}, 2021$, and first published online on January $7^{\text {th }}, 2022$, by Elsevier, Ltd. All rights reserved. All further use of this material other than for personal research is subject to permission from the publisher.

\title{
LAND USE/COVER CHANGE ANALYSIS IN THE MEDITERRANEAN REGION: A REGIONAL CASE STUDY OF FOREST EVOLUTION IN CASTELLÓ (SPAIN) OVER 50 YEARS
}

\author{
Rafael Delgado-Artés ${ }^{\mathrm{a}, *}$, Virginia Garófano-Gómez ${ }^{\mathrm{a}, \mathrm{b}}$, José-Vicente Oliver-Villanuevac, Eduardo Rojas-Briales ${ }^{\mathrm{c}}$ \\ a Institut d'Investigació per a la Gestió Integrada de Zones Costaneres (IGIC), Universitat Politècnica de València, \\ Paranimf 1, Grau de Gandia, 46730 València, Spain \\ b Université Clermont Auvergne, CNRS, GEOLAB, F-63000 Clermont-Ferrand, France \\ c Institute for Information and Communication Technologies (ITACA), Universitat Politècnica de València, 46022 \\ València, Spain \\ *Correspondence to: radelar@,upv.es
}

\begin{abstract}
The second half of the 20th century has been characterised by the rural abandonment in several regions of the Mediterranean basin. The general collapse of traditional agriculture and livestock activities brought about an intensive migration movement from inland to coastal areas, which produced a massive forest cover increase in abandoned rural areas. This socioeconomic, spatial and environmental change has led to a situation unknown for centuries in the Mediterranean landscapes. As a consequence, large wildfires have increased enormously in importance in a society with a predominant urban vision over the rest of the territory. Indeed, public opinion considers wildfires as major natural disturbances related to climate change causing at the end deforestation, while its prerequisite, a substantial increase of forest cover due to rural collapse, is less known. This research aimed to deepen the knowledge about forest evolution and its implications after the land abandonment process that started in the second half of the 20th century. The substantive source of information was obtained from a photointerpretation by sampling, using five general land-cover and land-use types and four specific land-cover types over a period of 50 years (1957-2007) in the province of Castelló (Valencian Region, Spain). Results showed that the area dominated by dense forests (shrublands and woodlands) has increased from $17 \%$ to $28 \%$, and the area dominated by their transitional land uses after farming abandonment has increased from $8 \%$ to $21 \%$. Transition matrices enabled a precise identification of changes among dominant categories over the studied period. Random and systematic transitions between categories have been analysed and a map of forest evolution pathways could be drawn, in which a double alternative path was identified. In the general context of progressive evolution to dense forests in the Mediterranean region, we have also found different evolution rates which may depend on site conditions. Their specific soil and climatic factors should be further analysed in order to improve our understanding of future forest evolution in the Mediterranean region at a local scale. A robust knowledge of these processes will contribute to improve forest management and land-use planning while optimising resilience, carbon storage and the provision of environmental services.
\end{abstract}

\section{Keywords}

Land use; Land cover; Rural abandonment; Forest evolution path; Transition matrix 
The Iberian Mediterranean region experienced its most intensive historically-known rural transformation in the past 150 years, which began at the end of the 19th century and intensified during the second half of the 20th century, in form of two waves (1860-1936 and 1955-present) interrupted by the Spanish Civil War and its harsh post-war period (Camarero, 1991; Ortega and Cobo, 2004). While the first wave was softened by the Spanish demographic transition (Arranz,1980; Reher and Sanz-Gimeno, 2007; Robles et al., 1996b, 1996a) and interrupted by the civil war, the second had much more intensive effects, breaking the social and spatial structures of large rural areas (Collantes, 2007, 2001). This second period is the selected time frame for this research.

Simultaneously with industrialisation and service development processes (Lizárraga and Chica-Olmo, 2014), huge migrations took place from rural areas to large cities and, in general, from inland to the coast (Heredia-Laclaustra et al., 2013). These transformations happened later in comparison to the countries of Central and Northern Europe and faster (especially between 1955 and 1975), without any socioeconomic and spatial strategic planning (MataixSolera and Cerdà, 2009).

While the urban and coastal areas had unprecedented economic and social transformations, in the rural areas population and farming progressively collapsed in many regions (Collantes, 2007). Currently, a large part of the territory has the lowest population densities since the Neolithic transition of the population (Badal, 2017; Muñoz-

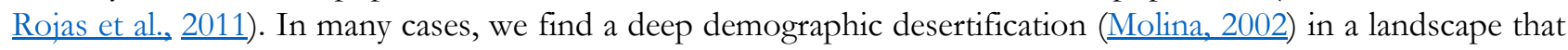
had been shaped by more than 5000 years of human activities, first by the use of fire and later by grazing, agriculture and wood collection (Bauer, 2003; Blondel, 2006). In fact, the value of the Mediterranean cultural landscape as a hotspot of global biodiversity (Myers et al.,2000) is precisely the consequence of the integration between its natural heterogeneity and human processes developed over millennia (EFI, 2009; Guadilla-Sáez et al., 2019; Muñoz-Rojas et al., 2019; Otero, 2010).

This new context brings some challenges and, for instance, García and Lasanta (2018) consider that the present Mediterranean cultural landscape is undergoing a process of deconstruction that involves serious economic, ecological and social changes because of the cessation of traditional human activities. Forests without any management for the first time in history are colonising new areas, reaching its largest historical known extension (Cervera et al, 2015) and densifying their structure where they already existed, according to the available information (Casals et al., 2005; Cervera et al., 2019; Villanueva, 2005).

As a consequence of this new context, since 1980 (Vélez, 2000) large wildfires have taken the leading role as the most important disruptive agents of forest expansion (Castellnou et al., 2007). Wildfires are becoming first-level emergencies of increasing dimensions (Pausas et al., 2008; Rifà and Castellnou, 2007), since they are evolving towards larger events with more catastrophic consequences (Castellnou et al., 2009, 2007; Garavaglia and Besacier, 2014; Moreno, 2007; Vélez, 2018), and with serious environmental and socioeconomic damages at local, regional and global scales (Martín et al., 1998) in the context of great threats due to global change (Lindner et al., 2010; Moreno et al., 2005). This new situation has also led to critical effects on the biodiversity, as many species have evolved into a mixed-use landscape that offers much more varied habitat conditions for them than closed shrublands and forests (Vallecillo, 2009).

If urgent policies are not implemented, the population of inland rural areas will continue to decline (Alamá-Sabater et al., 2021; Camarero et al., 2009; Pinilla and Sáez, 2017) and, therefore, the landscape will remain losing the last elements of its traditional management, while the urban population will continue to grow (Pinilla and Sáez, 2017), increasingly disconnected from its rural roots and territory. This context provides the basis for a new emerging environmentally-driven narrative quite disjointed from the facts and historical background (Meira et al., 2013; Otero, 2010). In any case, this urban population in the future will require considerable environmental services provided by natural resources (CITMA, 2012; Reid et al., 2005), and consequently, forests would need to be planned and managed in new sustainable ways.

Understanding trends in landscape evolution, particularly those related to the linkage between rural and urban areas, is crucial for sustainable spatial planning (Di Fazio et al., 2011), both from the socioeconomic and environmental points of view. Some authors classify the processes that explain landscape changes into 
socioeconomic and ecologic (Bakker and Veldkamp, 2008; Rindfuss et al., 2004; Serra et al., 2014) although they have evident relationships with each other (Corbelle-Rico et al., 2012; Serra et al., 2014; Vidal-Macua et al., 2018; Weissteiner et al., 2011). Various authors advocate for integrative approaches in long-term studies, recognizing the social and natural coevolution of the Mediterranean landscape (Blondel, 2006).

In the same way, it is important to understand the evolution of forest ecosystems as well as their planning (PeñaAngulo et al., 2019), either for the sustainable management of its multiple resources, for risk prevention, such as wildfires and pests (Castellnou et al., 2007; Rubio-Cuadrado et al., 2021), for the forecasting of $\mathrm{CO}_{2}$ stock evolution or adaptation to climate change (Lindner et al., 2010).

The evolution of forests has traditionally been studied in detail and systematised in patterns of forest type changes, explained by the ecological theory under different trajectories or paths, often reductionist (Walker, 2005), sometimes deterministic, according to the spatial and temporal scale of the study and environmental drivers (Estrada-Villegas et al., 2020), with facilitation steps between different stages of vegetation (Siles et al., 2008). In fact, the concept of succession, progressive or regressive (Ferriol and López, 2016; Margalef, 1993; Odum and Barret, 2006), is one of the oldest and most generalisable ecological concepts and constitutes a rich foundation for many ecological theories about vegetation dynamics (Pickett et al., 2009).

In general, the evolution of forest types is classified as progressive, implying a trend towards forests with higher density and vegetal maturity, or the opposite, regressive, due to disturbances, deforestation, forest degradation or environmental changes (Buhk et al., 2006; Margalef, 1993; Uríos, 2005). It is also possible to distinguish between external and internal forest evolution. In the first case, involving exchanges between forest and non-forest land uses, and in the second case, regarding transitions within forest types. External forest evolution is closely related to human uses: Humans can remove forests to use the land and, on the other hand, when a human use is abandoned, secondary forest evolution can begin (Peña-Angulo et al., 2019). Internal forest evolution, progressive or regressive, depends mainly on the natural conditions of the site, although there may be human disturbances that, without affecting the forest nature of the land, might produce a thinning of the vegetation, such as extensive sheepherding or wood extraction. These activities were intensively developed during centuries until their decline, in accordance with the aforementioned rural transformation.

Estimating the future evolution of forest resources in a territory requires knowing what the immediate previous evolution has been, in order to determine what their patterns are, not only depending on natural factors but also on socioeconomic ones (Verburg et al., 2010). Moreover, a large spatial and temporal scale is needed in order to understand the qualitative and quantitative evolution of forests and represent their general trends, beyond particular situations, taking into account the very diverse conditions in large territories (Martínez-Fernández et al., 2015) and the typical slowness, from a human time perspective, in the evolution of forest types (Lasanta and Vicente-Serrano, 2007; Rindfuss et al., 2004).

Studying the past trends of forest evolution allows us to predict how future forests are expected to evolve, both in qualitative and quantitative terms. Thus, the overall aim of this research is to understand on the main changing trends of land-use and land-cover types at a regional scale in a large coastal Mediterranean territory, with emphasis on the paths of forest evolution, during a 50-year time period, in the specific case selected. To do this, the province of Castelló (Valencian Region, Spain) was chosen as a representative case study of the Mediterranean region. This research is also strategic in the framework of a comprehensive debate around rural decline in certain areas of Europe and its consequences, but especially in the Iberic Peninsula (ojas-Briales et al., 2018).

\section{Study area}

The province of Castelló, with an extension of $6632 \mathrm{~km}^{2}$, has a very large forest area (68\%), significantly higher than the Valencian Region (57\%) and Spain (55\%). This study area, located between the latitudes $40^{\circ} 50^{\circ} \mathrm{N}$ and $39^{\circ} 40^{\prime} \mathrm{N}$ and the longitudes $0^{\circ} 5^{\prime} \mathrm{W}$ and $0^{\circ} 3^{\prime} \mathrm{E}$, has parallel and perpendicular mountainous alignments with each other and the coastline that directly condition climatology in an altitudinal gradient between sea level and 1814 m.a.s.l. (Figure 1). 

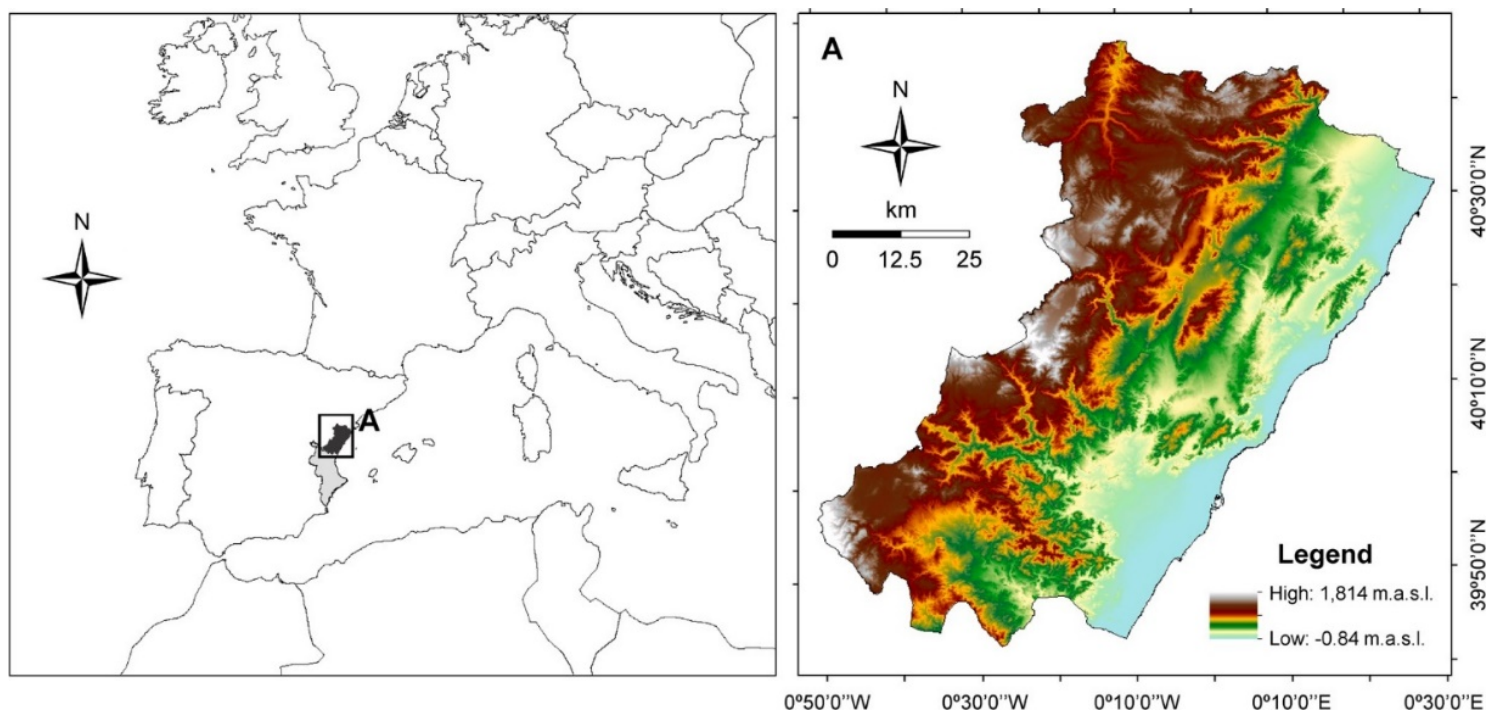

Figure 1. Inside the square (A), geographic location of the province of Castello within the Western Mediterranean and the Valencian Region (left). Elevation map of Castelló (right).

In Castelló, all the thermotypic horizons between the lower thermomediterranean and the upper supramediterranean (Allúe, 1990; Rivas-Martínez et al., 2011b) are represented, resulting in a large diversity of ecosystems in addition to areas with high forest maturity and productivity, dominated by wooded forests $(60 \%$ of the forest territory). The main dominant tree species (Figure 2) in the lower lands are Pinus halepensis Miller and Quercus ilex L. while Pinus nigra Arnold and Pinus sylvestris L. dominate in the higher areas (CITMA, 2012).
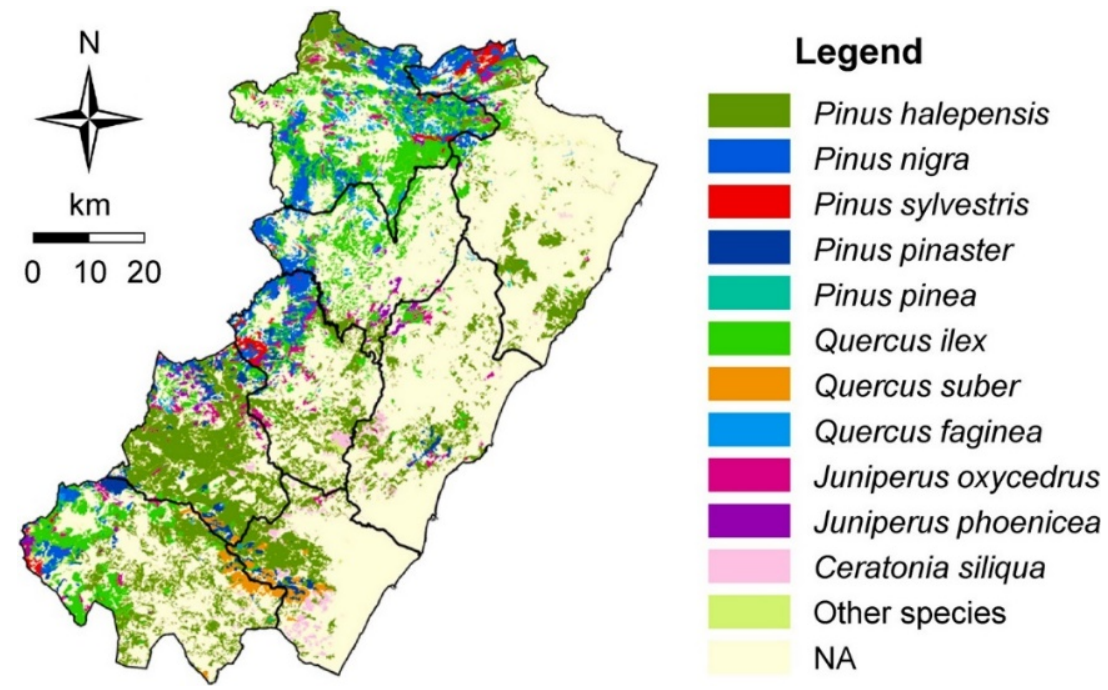

Figure 2. Dominant tree species in the forests of Castelló (ITMA, 2012).

As a coastal territory with inland mountainous areas, this province has strongly experienced the depopulation processes in the non-coastal areas (Alo and Pontius, 2008; Valera et al., 2017) versus an increasingly populated urban coast (Figure 3), with a large accumulation of infrastructures also causing considerable environmental impacts (Olcina, 2009). In this sense, the interior of Castelló has the highest indicators of rurality in the Valencian Region (Solsona and López, 2012) and consequently, it is one of the Spanish territories whose imbalances between inland and coastal areas at a territorial and socioeconomic level are deeper. 

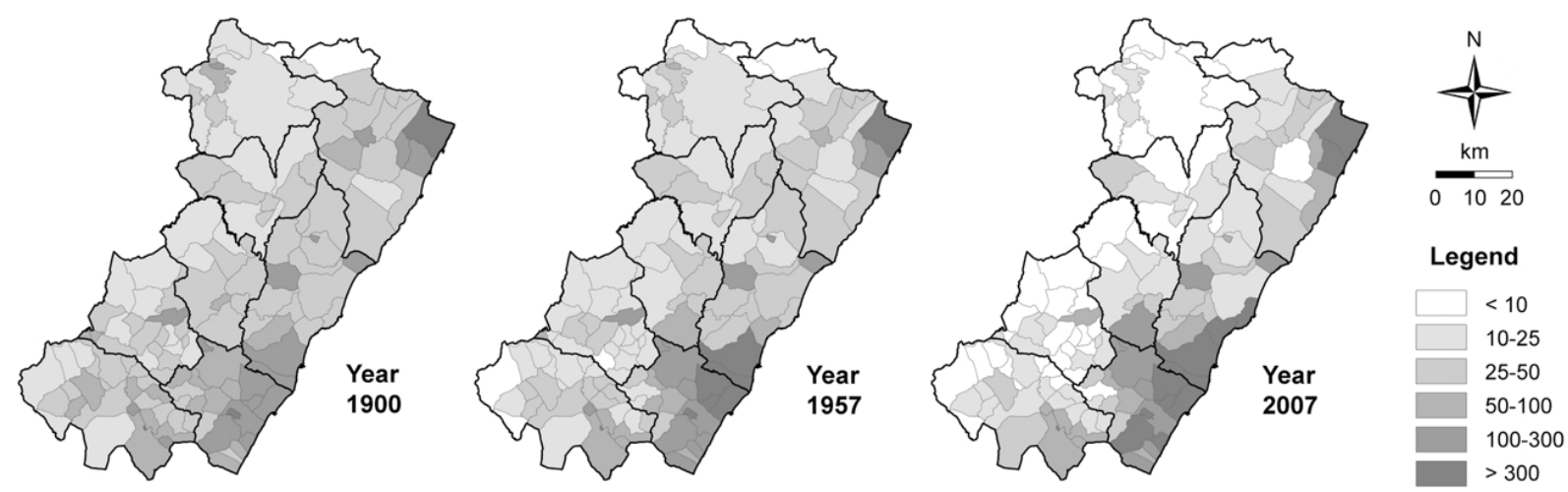

Figure 3. Population density (habitants $/ \mathrm{km}^{2}$ ) in the municipalities of Castelló in 1900, 1957 and 2007.

Urban and coastal areas have experienced unprecedented economic and social transformations, known as tertiarisation (Gámir et al., 1989; Lizárraga and Chica-Olmo, 2014), i.e. a continuous shift from the primary and secondary sectors to the tertiary sector. Thus, the socioeconomic importance of agriculture has clearly diminished in the study period: while in 1960 the weight of the agricultural sector in the labor market reached $42.5 \%$ of the workforce, it dropped to just 3,7\% in 2002. In terms of Gross Domestic Product, it dropped from 29\% in 1960 to $2.9 \%$ in 2002, showing the sharpest decline between 1960 and 1975 (Soler and Marco, 2004).

As a consequence of forest densification caused by rural abandonment (Pausas and Fernández-Muñoz, 2012), forest fires have become the most important disturbances in the period. Like the rest of the Valencian Region, statistics from 1968 show how annual forest fires are climate dependent and have an irregular behaviour (Franco et al., 2019). Taking into account this irregularity, two periods are distinguishable in the trend of forest fires in Castelló (Ferran et al., 2003). Before 1993, the annual number of wildfires and the total area affected by them tended to increase. After 1993, the regime has been modified due to a significant improvement of the fire extinction services. As a result of this, the annual and area affected by forest fires have been greatly reduced and later stabilised, but the problem has moved to the increasing size of those few large fires that cannot be controlled in the first attempts by the extinction services, causing huge emergencies. The recurrence or repetition of fires in the period for which data are available is very low in the area chosen for this research (Quílez, 2019).

\section{Methods}

\subsection{Data acquisition}

The specific information for this research was obtained from two sets of aerial images taken in an exact interval of 50 years between them: the first, from the so-called American flight of the B series, made between July and August 1957 by the American Army Map Service; and the second set from the digital orthophotos of the flight made between August and September 2007, within the Spanish National Program for Aerial Orthophoto. The technical characteristics and the providers of these images are presented in Table 1.

Table 1. Characteristics of the two sets of aerial images. In the case of the 1957 image, the minimum scale and resolution are indicated.

\begin{tabular}{llcc}
\hline Year & \multicolumn{1}{c}{ Organism } & Scale & Resolution (m) \\
\hline 1957 & Spanish Air Force (CECAF) & $1: 33000$ & 1.0 \\
2007 & Spanish National Program for Aerial Orthophoto & $1: 5000$ & 0.5 \\
\hline
\end{tabular}

The time span covered by both images included the period of deep socioeconomic and environmental changes described in the Introduction and it can be considered long enough to observe significant changes in land uses, in 
general, and in forest types, in particular. Despite the differences in time and spatial resolution, the 1957 images proved to have adequate quality for the photointerpretation of vegetation, as evidenced in many previous studies based on this imaginery (García-Romero et al., 2010; Martínez-Fernández et al., 2015; Muñoz-Rojas et al., 2011; Teixidó et al., 2010).

A photointerpretation was carried out by sampling in both sets of images, specifically in a network of square plots of $100 \mathrm{~m}$ on each side ( $1 \mathrm{ha}$ ). This sampling network had a systematic raster distribution and the centre of symmetry of each plot coincided with the crossing points of the UTM mesh of the topographic map at a scale of 1:25000 $(\underline{\mathrm{ICV}, 2001})$, with a separation of $1 \mathrm{~km}$ from each other, resulting in a sampling intensity of 1 ha per $\mathrm{km}^{2}(1 \%)$.

\subsection{Land uses and land covers: multi-temporal analysis}

A multi-temporal analysis has been applied to evaluate the territorial distribution of land-use and land-cover types (hereafter, LULC) and their change over time. This type of analysis allows to establish spatial change patterns and predict their future evolution (Arnáez et al., 2008; Magalhaes, 2009).

Although there are some proposals for systematic and hierarchical classifications whose bases are accepted throughout the world and a governmental system accepted throughout Europe for large-scale use (Bossard et al., 2000; Büttner et al., 2004), there is no complete consensus in the scientific literature on the classification by categories in the studies of LULC evolution. Thus, according to territorial characteristics and the specific aims in each study, different categories have been defined and applied.

However, where there is a general consensus in the scientific literature is in the distinction between land-use and land-cover types. So, land-use types are the result of human activities that modify the land surface, while landcover types refer to the natural or semi-natural lands mainly dominated by biophysical processes, although there could exist evidence of modification by human activities (Bakker and Veldkamp, 2008; Fisher, Comber, and Wadsworth, 2005; Rindfuss et al., 2004).

According to territorial characteristics and the sensitivity required, this research has implemented a classification (Table 2) with two levels of detail: one more general (Level I) and another more specific (Level II) with classes mutually exclusive (Anderson et al., 1976; Di Fazio et al. 2011; Fisher et al., 2005) and clearly identifiable. Although the main objective of this research was to assess the evolution of the forest types, we also took into account other LULC types, as there could be interchanges between any category, for example in the case of external forest evolution on previous human uses turned into forests. For this reason, forest types were studied in more detail, with a Level II scale, while for the rest of LULC types only Level I was applied.

Table 2. Land-use and land-cover (LULC) types. Level I refers to a more general classification and Level II to a more specific classification.

\begin{tabular}{ll}
\hline \multicolumn{1}{c}{ Covers and general uses (Level I) } & \multicolumn{1}{c}{ Specific covers (Level II) } \\
\hline & 1.1. Woodlands (FF); [cover $]$ \\
1. Forest types (FOR); [covers $]$ & 1.2. Shrublands (FS); [cover $]$ \\
& 1.3. Extensive natural grasslands and rocky outcrops (FGR); [cover $]$ \\
2. Abandoned agriculture (AA); [cover $]$ & \\
3. Agriculture (AG); [use $]$ & \\
4. Urban (U); [use $]$ & \\
5. Other land uses and land covers $(\mathrm{O}) ;[$ mixed $]$ &
\end{tabular}

In Level I, three clear LULC types were distinguished: agricultural land (AG), urban use (U) and forests land (FOR). Additionally, a category corresponding to abandoned agricultural crops (AA) was also included. 
AA is a transition cover that evolves from an agricultural land towards a forest cover if the former agricultural land is not recultivated again (Peña-Angulo et al., 2019). As soon as agricultural land is abandoned, a ruderal vegetation, predominantly herbaceous and therefore with little biomass, covers the ground (see Figure 4).
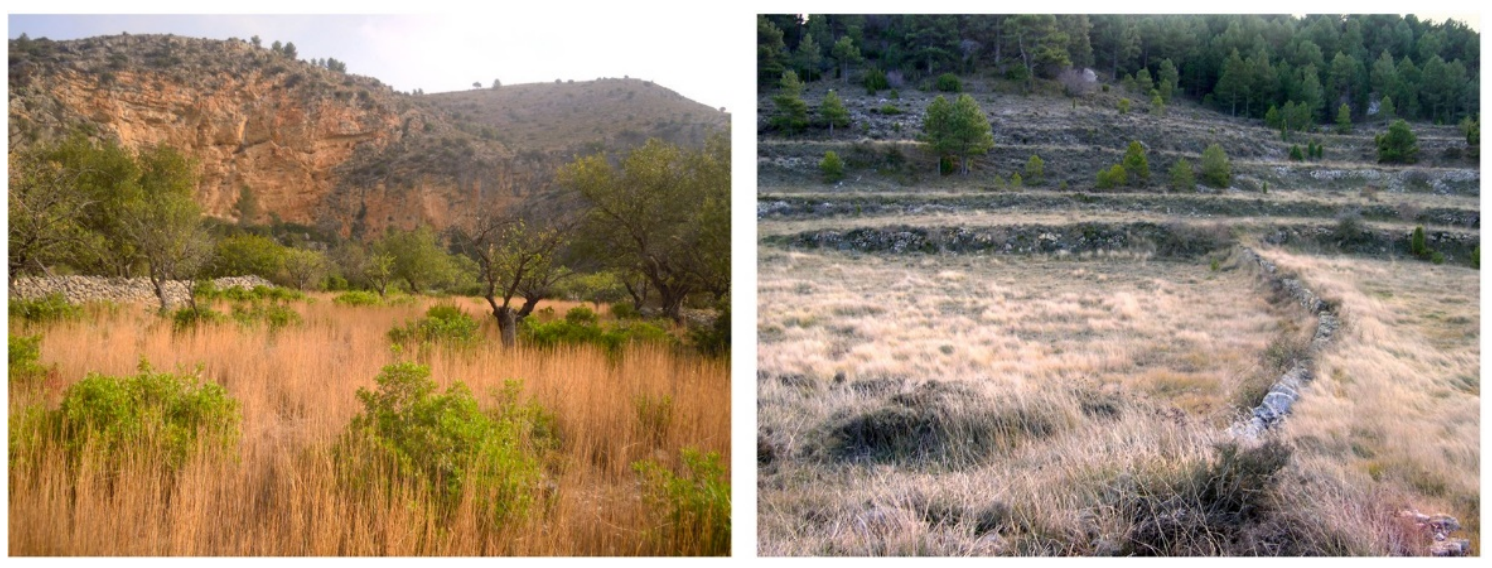

Figure 4. Agricultural lands that have been abandoned for approximately 25 years in an area with a thermomediterranean thermotype (left) and in an area with a supramediterranean thermotype (right) in the province of Castelló.

Traditionally, abandoned agricultural land presents considerable problems in the way they are treated in different Spanish statistics and in their legal status as forest or agricultural land. As this research is focusing on LULC types and not plots, the consideration of AA as a transitional cover following other authors (Arnaez et al., 2011; Vadell et al., 2019), means that this land-cover type of Level I cannot be assigned neither to agricultural uses nor to forest covers.

In Level II, three categories of forest types were included: woodlands (FF), shrublands (FS) and extensive natural grasslands and rocky outcrops (FGR). These forest types have been distinguished from each other by their vegetation structure or physiognomic forms. So, FF and FS are densely vegetated, and therefore will be named in this study as "dense forest covers" (or types), while FGR is a deforested cover consisting of rocky outcrops and natural grasslands and thus, mainly composed of herbaceous and sparse vegetation. This last cover has been historically related to traditional livestock activity (Soriano, 2003), and since the 1980s to wildfires (Martín et al. 1998; Vélez, 2018).

In any taxonomy, especially when applied on a regional scale, some cases are difficult to classify. This is due to their low representation level, or their difficult identification according to the scale or methodology for image analysis (Anderson et al., 1976), or even for other reasons like the natural heterogeneity of the Mediterranean landscapes (Alrababah and Alhamad, 2006). In our case, other land uses and land covers (O) included typologies not contained in any of the previous categories, such as beaches, reservoirs, wetlands, riverbeds, earthworks, landfills, quarries or riparian vegetation.

Photointerpretation required a training period supported by fieldwork, which included the field visit of $7 \%$ of the first 1000 points photointerpreted on the 2007 images, as a truth-terrain, with special emphasis on visiting areas that could present doubts in the photointerpretation or those that could represent a peculiar landscape pattern. A critical evaluation and verification system for quality control was also implemented, detecting unforeseen situations and adapting the methodology to adjust its operation.

In the sampling plots, land-use types appeared forming exclusive tiles and their assessment was carried out by measuring the surface that these tiles occupied within the plot. Instead, land-cover types could be randomly mixed in the same tile, and therefore to evaluate them it was necessary to use the canopy cover (CC) of each land cover. 
To evaluate the CC of the different forest covers, we first evaluated the one corresponding to FF, adapting visual assessment templates ( Kosztra et al., 2017; Van Laar and Akca, 2007) in order to estimate CC in 10\% steps from $5 \%$.

After this, CC of FS in the part of the plot not covered by FF was assessed. Unlike FF, CC of FS cannot be measured from individuals, since this coverage is characterised by a large number of stems, uncountable by photointerpretation. As a consequence, four density categories were defined, coinciding with the four quartiles of the CC between $0 \%$ and $100 \%$, which were weighted in each case by the surface extension of the formation.

The part of CC not occupied by FF or FS within the cover tile, corresponds to a herbaceous stratum, in any case not distinguishable from rocky outcrops by photointerpretation. Therefore, it was assigned to FGR or AA, depending on whether it was an old agricultural or forest plot and the characteristics of the background.

The condition of former agricultural plots can be observed by photointerpretation, not only by the ruderal vegetation but also according to the typical structures of Mediterranean agriculture, such as stone walls to level the terrain and separate properties. These structures have been used by several authors to assess agricultural abandonment (Arnaez et al., 2011; Poyatos et al., 2003) and do not offer any doubt about the context of former agricultural uses.

To study evolution trends, a generalisation was made and the predominant land type at each moment in each plot was considered as the final variable. Transition matrices were used to analyse the paths of change between categories (Verburg et al., 2010). Analysing them, we were able not only to evaluate evolutionary patterns but also to establish random and systematic transitions. A transition occurs randomly if a certain category gains from others in proportion to the availability of the losing classes and, at the same time, a class loses at random to other classes if the losses are in proportion to the size of the destination classes (Braimoh, 2006).

Pontius et al. (2004) introduced a methodology to analyse transition matrices in order to identify signals of systematic change, extended by Alo and Pontius (2008). The calculation of systematic transitions is made in terms of gains and losses separately. So, if class $i$ has a positive and systematic trend to lose to class $j$, and class $j$ systematically gains from class $i$, then it can be concluded that there is a systematic transition process from $i$ to $j$, whose significance and strength can be assessed. On the other hand, if both systematic trends are negative, it would mean a systematic resistance to the transition.

According to Alo and Pontius (2008), to calculate the gain that would be expected in class $j$ from class $i$ if it happens randomly, Eq. 1 has been used. It considers the quantities in percentage over the total in each case.

$$
\begin{aligned}
& G_{i j}=\left(P_{+j}-P_{j j}\right)\left(\frac{P_{i+}}{100-P_{j+}}\right) \\
& \forall i \neq j
\end{aligned}
$$

Where: $G_{i j}$ is the expected transition from category $i$ to category $j$ due to a random process of gain, $P_{+j}-P_{i j}$ is the observed total gross gain of category $j$ (final size in percentage of the category $j$ minus the persistent amount in $j$ ), $P_{i+}$ is the size of the category $i$ in the time 1 , and $100-P_{j^{+}}$is the sum of the sizes of all categories except the category $j$ in the time 1 .

To calculate the loss percentage that would be expected if the losses of each class occur at random, Eq. 2 has been used following Alo and Pontius (2008).

$$
\begin{aligned}
& L_{i j}=\left(P_{i+}-P_{i i}\right)\left(\frac{P_{+j}}{100-P_{+i}}\right) \\
& \forall i \neq j
\end{aligned}
$$


Where: $L_{i j}$ is the expected transition from category $i$ to category $j$ due to a random process of loss, $P_{i+}-P_{i i}$ is the observed total gross loss of category $i$ (original size of the category $i$, in percentage over the total, minus the persistent amount in $\imath$ ) between the moment 1 and the moment $2, P_{+j}$ is the size of category $j$ at the moment 2 and $100-P_{+i}$ is the sum of the sizes of all categories except the category $i$ at the moment 2.

To define the temporal patterns of forest evolution during the study period, systematic transitions were analysed in different directions (i.e., from, to and among forest types) applying transition matrices. To analyse spatial change

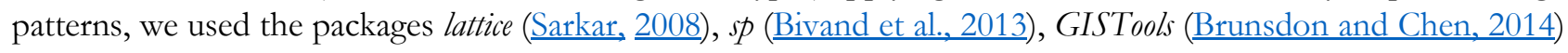
and networkD3 (Allaire et al., 2017) of the software R (

\section{Results}

\subsection{LULC changes}

The total number of plots sampled in the case study area was 6651. As a result of the photointerpretation, Table 3 shows the dominant LULC types in the sampled plots in 1957 and 2007 with the two levels of detail applied.

Table 3. Number and percentage of general (Level I) and specific (Level II) dominant land-uses and land-cover (LULC) types in the sampling plots in 1957 and 2007. FOR: Forest types; FF: Woodlands; FS: Shrublands; FGR: Extensive natural grasslands and rocky outcrops; AA: Abandoned agriculture; AG: Agriculture; U: Urban; O: Other land uses and land covers.

\begin{tabular}{cccccc}
\hline \multirow{2}{*}{ Level I } & Level II & \multicolumn{2}{c}{1957} & \multicolumn{2}{c}{2007} \\
\cline { 3 - 6 } & & $\begin{array}{c}\text { Number } \\
\text { of plots }\end{array}$ & $\%$ & $\begin{array}{c}\text { Number } \\
\text { of plots }\end{array}$ & $\%$ \\
\hline \multirow{2}{*}{ FOR } & FF & 825 & 12 & 1358 & 21 \\
& FS & 320 & 5 & 521 & 8 \\
AA & FGR & 2025 & 30 & 1676 & 25 \\
AG & & 512 & 8 & 1416 & 21 \\
U & & 2880 & 44 & 1353 & 20 \\
O & & 63 & 0 & 213 & 3 \\
Total & & 6651 & 1 & 114 & 2 \\
\hline
\end{tabular}

The sampling error obtained with a probability of 95\% differed for each LULC type, according to their frequency and distribution pattern (Table 4). For the forest covers, the relative sampling error was kept below 5\% in all cases. Regarding agricultural uses, this error was also moderate, unlike urban uses and other uses and covers, where the larger error was associated with a much smaller area occupied in the two dates.

The results indicate a large surface reduction in the categories related to agricultural and livestock uses, which represented the main land uses in 1957. Agricultural use (AG, Level I) decreases heavily from $44 \%$ of the sampling plots dominated in 1957 to 20\% in 2007. This land use does no longer occupy most of the landscape and, complementary, its decline has as direct consequence a drastic increase of the transition cover of abandoned agricultural crops (AA, Level I), which value (21\%) practically equals AG in 2007.

On the other hand, the land cover representing natural grasslands and rocky outcrops (FGR, Level II) dropped from $30 \%$ to $25 \%$ though becomes the predominant LULC category in the territory. The dense forest types, shrubland (FS) and woodland (FF) have experienced an important increase $(+12 \%)$ over abandoned agricultural uses and grasslands and rocky outcrops, which was especially important in the case of FF $(+9 \%)$. 
Table 4. Relative sampling error (RSE\%) of the different land-use and land-cover (LULC) types, at the 95\% confidence level. FOR: Forest types; FF: Woodlands; FS: Shrublands; FGR: Extensive natural grasslands and rocky outcrops; AA: Abandoned agriculture; AG: Agriculture; U: Urban; O: Other land uses and land covers.

\begin{tabular}{cccc}
\hline Level I & Level II & 1957 (RSE\%) & 2007 (RSE\%) \\
\hline \multirow{3}{*}{ FOR } & FF & 4.3 & 3.2 \\
& FS & 3.5 & 2.7 \\
& FGR & 2.8 & 2.9 \\
AA & & 8.1 & 3.9 \\
AG & & 2.7 & 4.5 \\
U & & 38.2 & 12.5 \\
O & & 21.7 & 17.2 \\
\hline
\end{tabular}

The evolution of the urban land use (U) displays a significant increase in relative terms (from less than 1\% in 1957 to $3 \%$ in 2007), but its absolute importance in the landscape is testimonial in comparison to the agricultural and forest cover types because its distribution is geographically concentrated, mainly along the coastal plains (Figure $5)$.

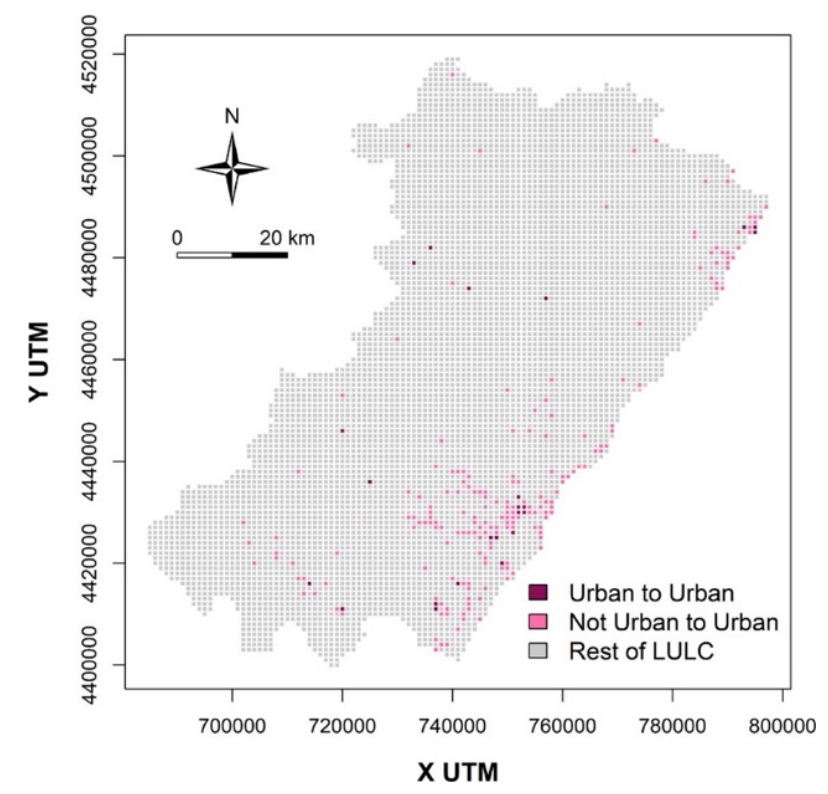

Figure 5. Spatial distribution of urban land-use change (urban plots that persist as urban and new urban areas) in the province of Castelló between 1957 and 2007.

The changes among the dominant LULC types in each plot are reflected in the transition matrix (Table 5), where the absolute transaction numbers between categories for the 50 -year time period can be observed. Furthermore, Table 5 presents the data standardised with the percentage of the initial amount of each category, which indicates the importance of each change path. Finally, Table 6 presents the exchanges in percentage referred to the final amount, indicating the origin of each plot dominated by each category in 2007.

Urban land use $(\mathrm{U})$ and other land uses and land covers $(\mathrm{O})$ present the highest standardised persistence during the 50 -year time period (100\% and $88 \%$, respectively), while the agricultural land use (AG) has the lowest (45\%), because of its large abandonment without any other alternative use (Table 5), which affected $48 \%$ of the plots with agricultural land use in 1957. 
Table 5. Transition matrix of the dominant land-use and land-cover (LULC) types in the plots sampled from 1957 and 2007 images. In brackets, relative transition changes (row percentages). FF: Woodlands; FS: Shrublands; FGR: Extensive natural grasslands and rocky outcrops; AA: Abandoned agriculture; AG: Agriculture; U: Urban; O: Other land uses and land covers.

\begin{tabular}{|c|c|c|c|c|c|c|c|c|c|}
\hline & & \multicolumn{8}{|c|}{2007} \\
\hline & & FF & FS & FGR & $\mathbf{A A}$ & AG & $\mathbf{U}$ & O & Total \\
\hline \multirow{8}{*}{$\stackrel{\mathfrak{n}}{2}$} & FF & $679(82)$ & $21(3)$ & $116(14)$ & $6(1)$ & $3(0)$ & $0(0)$ & $0(0)$ & 825 (100) \\
\hline & FS & $35(11)$ & $222(69)$ & $48(15)$ & $3(1)$ & $8(3)$ & $2(1)$ & $2(1)$ & $320(100)$ \\
\hline & FGR & $335(17)$ & $181(9)$ & $1463(72)$ & $6(0)$ & $20(1)$ & $14(1)$ & $6(0)$ & 2025 (100) \\
\hline & AA & $128(25)$ & $40(8)$ & $17(3)$ & $276(54)$ & $34(7)$ & $6(1)$ & $11(2)$ & $512(100)$ \\
\hline & AG & $179(6)$ & $56(2)$ & $30(1)$ & 1125 (39) & $1287(45)$ & $166(6)$ & $37(1)$ & $2880(100)$ \\
\hline & U & $0(0)$ & $0(0)$ & $0(0)$ & $0(0)$ & $0(0)$ & $23(100)$ & $0(0)$ & $23(100)$ \\
\hline & O & $2(3)$ & $1(2)$ & $2(3)$ & $0(0)$ & $1(2)$ & $2(3)$ & $58(88)$ & $66(100)$ \\
\hline & Total & 1358 & 521 & 1676 & 1416 & 1353 & 213 & 114 & 6651 \\
\hline
\end{tabular}

Table 6. Relative transition matrix of changes (column percentages on the 2007 amount) between dominant land-use and land-cover (LULC) types. FF: Woodlands; FS: Shrublands; FGR: Extensive natural grasslands and rocky outcrops; AA: Abandoned agriculture; AG: Agriculture; U: Urban; O: Other land uses and land covers.

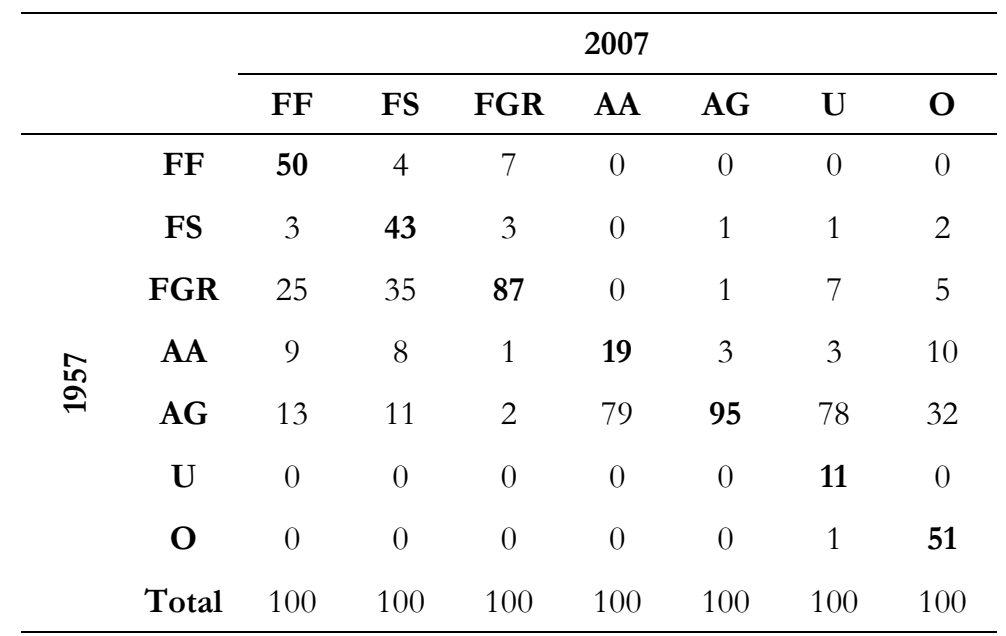

Figure 6 presents a Sankey diagram of the changes among LULC types between 1957 and 2007. There you can see the significant agricultural decline that has taken place, taking into account its previous territorial importance, as well as the rest of the changes that have been described.

The results show how the transitional land use of abandoned crops (AA) preexisting in 1957 has even a higher standardised persistence (54\%) than the agricultural land uses. Still, this land use has been partly colonised by forests (36\% of the 1957 plots), mainly by woodlands (25\%) and only a small part of the abandoned agricultural uses in $1957(7 \%)$ has been recultivated with agricultural crops in the 50-year time span.

Remarkable persistence was also observed in the forest types (woodlands FF $82 \%$, grasslands and rocky outcrops FGR 72\%, and shrublands FS 69\%). But beyond this, the dense forests (woodlands and shrublands, Level II) experienced very significant growth, as evidenced by the fact that only slightly less than half of the plots dominated by these covers in 2007 were dominated 50 years earlier by them (50\% of woodlands FF and $43 \%$ of shrublands FS). 
The overall increase in dense forest cover observed in the results can be divided into two components. Firstly, external forest evolution observed in the percentage of non-forestry categories in 1957 that has evolved towards forests until 2007 (36\% of the plots categorised in 1957 as AA, 9\% as AG and 8\% as O). This results in an important absolute increase in the total forest area, according to the large initial area of these categories, especially AG.

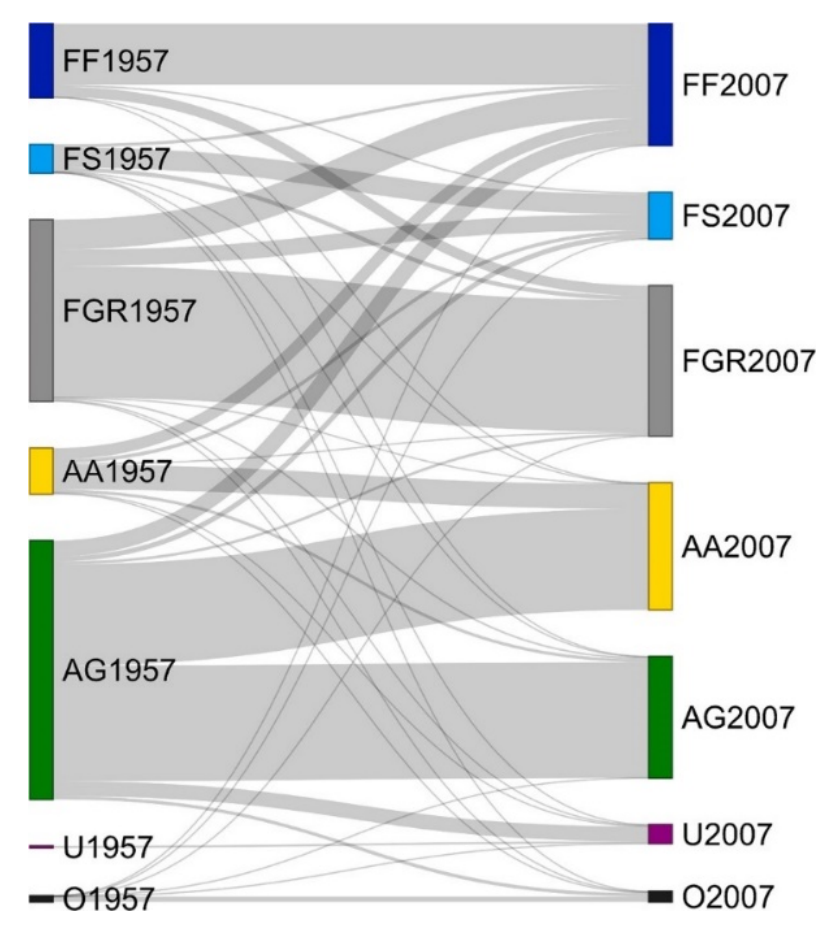

Figure 6. Sankey diagram of the absolute flow of plots associated with the different land-use and land-cover (LULC) types between 1957 and 2007. Note that the width of the lines is proportional to the number of plots represented (from the narrowest lines representing 0 exchange of plots between types to the widest line, which specifically represents the largest destination of 1463 plots of FGR in 1957 to FGR in 2007). The exact value of each transition change can be consulted in Table 5. FF: Woodlands; FS: Shrublands; FGR: Extensive natural grasslands and rocky outcrops; AA: Abandoned agriculture; AG: Agriculture; U: Urban; O: Other land uses and land covers.

Secondly, the internal evolution in the existing forests can be also clearly observed, although in this case, it has a double sense. On the one hand, this consists of a densification or progressive forest evolution to dense forest types affecting $26 \%$ of the FGR in 1957, more towards woodlands FF (17\%) than to shrublands FS (9\%). On the other hand, regressive forest evolution as the opposite path is followed by a smaller number of plots in absolute numbers, although in relative terms it meant important values due to the lower initial representation of these categories (14\% of woodlands, FF, and 15\% of shrublands, FS). Exchanges between dense forest types are lower from FF to FS in absolute and relative terms (3\%) than in the opposite direction (11\%). 

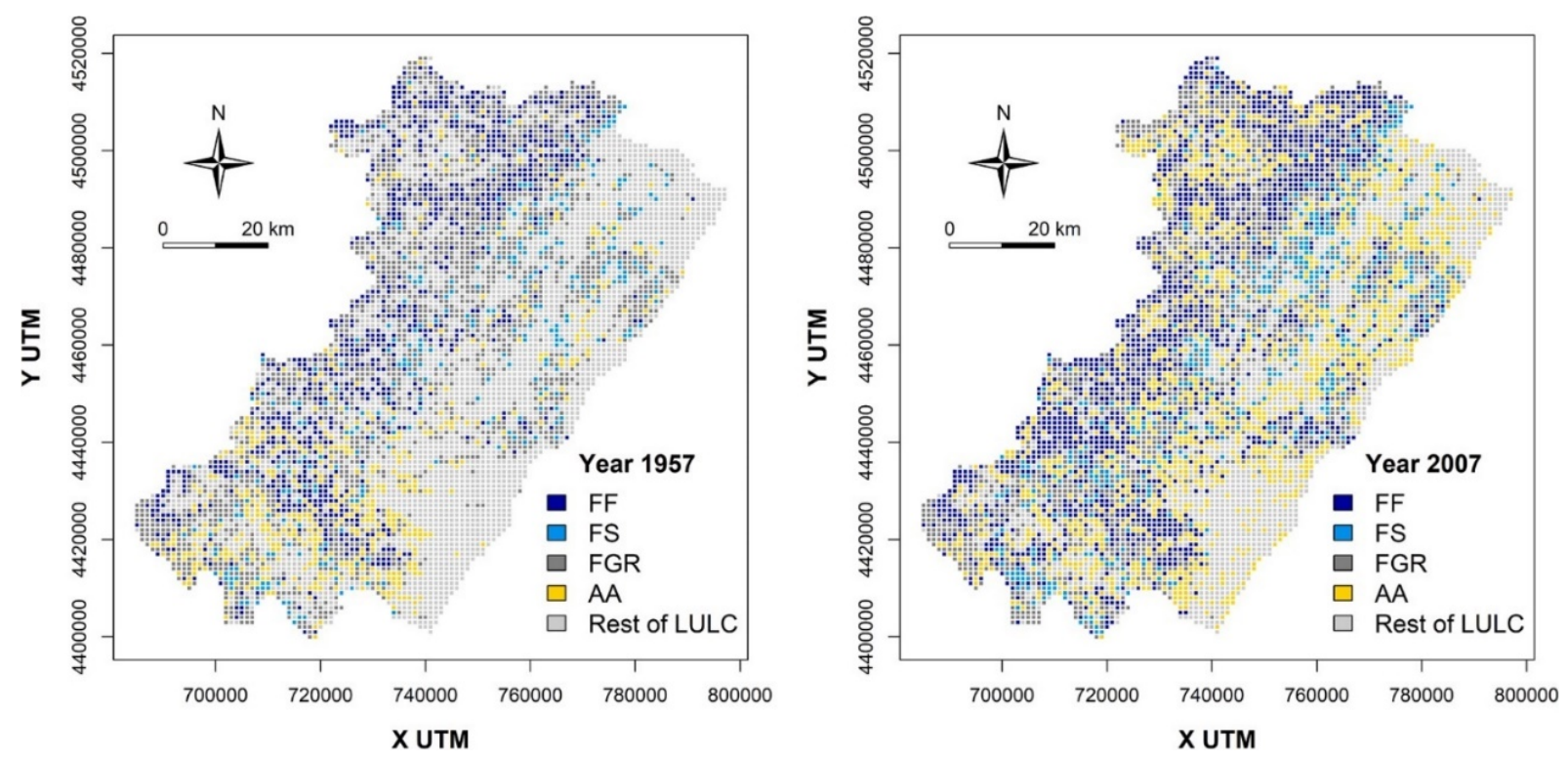

Figure 7. Abandoned agriculture cover (AA) and Level II dominant forest covers (FF: woodlands; FS: shrublands; FGR: extensive natural grasslands and rocky outcrops) in the plots in 1957 (left) and 2007 (right). "Rest of LULC" refers to the rest of land-use and land-cover categories not considered in this assessment.

Figure 7 presents the distribution of the dominant land-cover types in the case study area in both moments. The spatial patterns of the external and internal forest evolution can be observed on a large scale. Starting from a distribution restricted to the southern part of the province in 1957, AA spread throughout the territory in 2007. Likewise, the expansion of forests (mainly FF and FS) over a wide area can be also observed, although in the case of FS, there was mainly a pattern of coastal and pre-coastal distribution.

\subsection{Random and systematic transitions}

The expected transitions between categories of land-use and land-cover types have been compared with those produced in terms of gains (Table 7) and losses (Table 8). The upper left parts of each table indicate the relationships among the forest covers and the covers in transit to a forest cover, which allow us to analyse the systematic patterns of forest evolution.

Regarding internal forest evolution, some trends of systematic change between grasslands and rocky outcrops (FGR) and woodlands (FF) and shrublands (FS) can be observed, both progressive and regressive. The progressive changes occur in a larger number of plots (5.04\% from FGR to FF and 2.72\% from FGR to FS) than regressive ones (1.74\% from FF to FGR and $0.72 \%$ from FS to FGR). No systematic trends of change can be found between both dense forest types (FF and FS).

In external forest evolution, the strong systematic trend of dense forest types (especially FF) to grow over abandoned agricultural crops can be seen (ratio between difference and expected pass from AA to FF, 1.15 in terms of gains and 1.09 in terms of losses) and the systematic resistance to pass from any non-forest category to FGR can also be observed (negative ratios between difference and expected pass in terms of gains and in terms of losses in the pass from all of them to FGR). Furthermore, the obtained results indicate that, in general terms, there is also no systematic trend to replace forest with any other non-forest land use, but rather there is a systematic resistance to the replacement of FF and FGR by any other non-forest category.

Concerning the non-forest categories, the main systematic trends during the period confirm the general loss of agricultural uses (AG) and the gain of urban uses $(U)$ mentioned before. Agricultural uses tend systematically to be abandoned (transition to AA, $16.91 \%$ of plots) without any opposite systematic trend. 
Table 7. Matrix of the percentage of change in terms of gains. The first value (in bold) refers to the observed percentage of change between categories; the second value (in italics), to the expected percentage of change if the change process were random; the third value (in brackets), to the observed value minus the expected one; and the fourth value (in square brackets), to the ratio between the previous value and the expected one. FF: Woodlands; FS: Shrublands; FGR: Extensive natural grasslands and rocky outcrops; AA: Abandoned agriculture; AG: Agriculture; U: Urban; O: Other land uses and land covers.

\begin{tabular}{|c|c|c|c|c|c|c|c|c|c|}
\hline & \multicolumn{9}{|l|}{2007} \\
\hline & FF & FS & FGR & AA & AG & $\mathbf{U}$ & $\mathbf{O}$ & 1957 & Loss \\
\hline \multicolumn{10}{|l|}{1957} \\
\hline \multirow[t]{4}{*}{ FF } & 10.21 & 0.32 & 1.74 & 0.09 & 0.05 & 0.00 & 0.00 & 12.40 & 2.20 \\
\hline & 10.21 & 0.59 & 0.57 & 2.30 & 0.22 & 0.36 & 0.11 & 14.35 & 4.14 \\
\hline & $(0.00)$ & $(-0.27)$ & (1.17) & $(-2.21)$ & $(-0.17)$ & $(-0.36)$ & $(-0.11)$ & $(-1.94)$ & $(-1.94)$ \\
\hline & {$[0.00]$} & {$[-0.46]$} & [2.05] & {$[-0.96]$} & {$[-0.79]$} & {$[-1.00]$} & {$[-1.00]$} & {$[-0.14]$} & {$[-0.47]$} \\
\hline \multirow[t]{4}{*}{ FS } & 0.53 & 3.34 & 0.72 & 0.05 & 0.12 & 0.03 & 0.03 & 4.81 & 1.47 \\
\hline & 0.56 & 3.34 & 0.22 & 0.89 & 0.08 & 0.14 & 0.04 & 5.28 & 1.94 \\
\hline & $(-0.03)$ & $(0.00)$ & $(0.50)$ & $(-0.85)$ & $(0.04)$ & $(-0.11)$ & $(-0.01)$ & $(-0.47)$ & $(-0.47)$ \\
\hline & {$[-0.06]$} & {$[0.00]$} & {$[2.26]$} & {$[-0.95]$} & {$[0.43]$} & {$[-0.78]$} & {$[-0.27]$} & [-0.09] & {$[-0.24]$} \\
\hline \multirow[t]{4}{*}{ FGR } & 5.04 & 2.72 & 22.00 & 0.09 & 0.30 & 0.21 & 0.09 & 30.45 & 8.45 \\
\hline & 3.55 & 1.44 & 22.00 & 5.65 & 0.53 & 0.87 & 0.26 & 34.30 & 12.30 \\
\hline & $(1.49)$ & $(1.28)$ & $(0.00)$ & $(-5.56)$ & $(-0.23)$ & $(-0.66)$ & $(-0.17)$ & $(-3.85)$ & $(-3.85)$ \\
\hline & {$[0.42]$} & [0.89] & {$[0.00]$} & {$[-0.98]$} & {$[-0.44]$} & {$[-0.76]$} & {$[-0.65]$} & {$[-0.11]$} & {$[-0.31]$} \\
\hline \multirow[t]{4}{*}{ AA } & 1.92 & 0.60 & 0.26 & 4.15 & 0.51 & 0.09 & 0.17 & 7.70 & 3.55 \\
\hline & 0.90 & 0.36 & 0.35 & 4.15 & 0.13 & 0.22 & 0.07 & 6.19 & 2.04 \\
\hline & (1.03) & $(0.24)$ & $(-0.10)$ & $(0.00)$ & $(0.38)$ & $(-0.13)$ & $(0.10)$ & $(1.51)$ & (1.51) \\
\hline & [1.15] & {$[0.65]$} & {$[-0.28]$} & {$[0.00]$} & [2.79] & {$[-0.59]$} & [1.53] & [0.24] & {$[0.74]$} \\
\hline \multirow[t]{4}{*}{ AG } & 2.69 & 0.84 & 0.45 & 16.91 & 19.35 & 2.50 & 0.56 & 43.30 & 23.95 \\
\hline & 5.05 & 2.05 & 1.99 & 8.04 & 19.35 & 1.24 & 0.37 & 38.09 & 18.74 \\
\hline & $(-2.36)$ & $(-1.20)$ & $(-1.54)$ & $(8.87)$ & $(0.00)$ & $(1.25)$ & $(0.19)$ & $(5.22)$ & $(5.22)$ \\
\hline & {$[-0.47]$} & {$[-0.59]$} & {$[-0.77]$} & {$[1.10]$} & {$[0.00]$} & [1.01] & {$[0.51]$} & {$[0.14]$} & {$[0.28]$} \\
\hline \multirow[t]{4}{*}{$\mathbf{U}$} & 0.00 & 0.00 & 0.00 & 0.00 & 0.00 & 0.35 & 0.00 & 0.35 & 0.00 \\
\hline & 0.04 & 0.02 & 0.02 & 0.06 & 0.01 & 0.35 & 0.00 & 0.49 & 0.15 \\
\hline & $(-0.04)$ & $(-0.02)$ & $(-0.02)$ & $(-0.06)$ & $(-0.01)$ & $(0.00)$ & $(0.00)$ & $(-0.15)$ & $(-0.15)$ \\
\hline & {$[-1.00]$} & {$[-1.00]$} & {$[-1.00]$} & {$[-1.00]$} & [-1.00] & {$[0.00]$} & {$[-1.00]$} & {$[-0.30]$} & {$[-1.00]$} \\
\hline \multirow[t]{4}{*}{$\mathbf{O}$} & 0.03 & 0.02 & 0.03 & 0.00 & 0.02 & 0.03 & 0.87 & 0.99 & 0.12 \\
\hline & 0.12 & 0.05 & 0.05 & 0.18 & 0.02 & 0.03 & 0.87 & 1.31 & 0.44 \\
\hline & $(-0.09)$ & $(-0.03)$ & $(-0.02)$ & $(-0.18)$ & $(0.00)$ & $(0.00)$ & $(0.00)$ & $(-0.32)$ & $(-0.32)$ \\
\hline & {$[-0.74]$} & {$[-0.68]$} & {$[-0.34]$} & {$[-1.00]$} & {$[-0.13]$} & {$[0.06]$} & {$[0.00]$} & {$[-0.24]$} & {$[-0.73]$} \\
\hline \multirow[t]{4}{*}{2007} & 20.42 & 7.83 & 25.20 & 21.29 & 20.34 & 3.20 & 1.71 & 100.00 & 39.74 \\
\hline & 20.42 & 7.83 & 25.20 & 21.29 & 20.34 & 3.20 & 1.71 & 100.00 & 39.74 \\
\hline & $(0.00)$ & $(0.00)$ & $(0.00)$ & $(0.00)$ & $(0.00)$ & $(0.00)$ & $(0.00)$ & $(0.00)$ & $(0.00)$ \\
\hline & {$[0.00]$} & {$[0.00]$} & {$[0.00]$} & {$[0.00]$} & {$[0.00]$} & {$[0.00]$} & {$[0.00]$} & {$[0.00]$} & {$[0.00]$} \\
\hline \multirow[t]{4}{*}{ Gain } & 10.21 & 4.50 & 3.20 & 17.14 & 0.99 & 2.86 & 0.84 & 39.74 & \\
\hline & 10.21 & 4.50 & 3.20 & 17.14 & 0.99 & 2.86 & 0.84 & 39.74 & \\
\hline & $(0.00)$ & $(0.00)$ & $(0.00)$ & $(0.00)$ & $(0.00)$ & $(0.00)$ & $(0.00)$ & $(0.00)$ & \\
\hline & {$[0.00]$} & {$[0.00]$} & {$[0.00]$} & {$[0.00]$} & {$[0.00]$} & {$[0.00]$} & {$[0.00]$} & {$[0.00]$} & \\
\hline
\end{tabular}


Table 8. Matrix of the percentage of change in terms of losses. The first value (in bold) refers to the observed percentage of change between categories; the second value (in italics), to the expected percentage of change if the change process were random; the third value (in brackets), to the observed value minus the expected one; and the fourth value (in square brackets), to the ratio between the previous value and the expected one. FF: Woodlands; FS: Shrublands; FGR: Extensive natural grasslands and rocky outcrops; AA: Abandoned agriculture; AG: Agriculture; U: Urban; O: Other land uses and land covers.

\begin{tabular}{|c|c|c|c|c|c|c|c|c|c|}
\hline & \multicolumn{9}{|l|}{2007} \\
\hline & FF & FS & FGR & AA & AG & $\mathbf{U}$ & $\mathbf{O}$ & 1957 & Loss \\
\hline \multicolumn{10}{|l|}{1957} \\
\hline \multirow[t]{4}{*}{ FF } & 10.21 & 0.32 & 1.74 & 0.09 & 0.05 & 0.00 & 0.00 & 12.40 & 2.20 \\
\hline & 10.21 & 0.22 & 0.70 & 0.59 & 0.56 & 0.09 & 0.05 & 12.40 & 2.20 \\
\hline & $(0.00)$ & $(0.10)$ & (1.05) & $(-0.50)$ & $(-0.52)$ & $(-0.09)$ & $(-0.05)$ & $(0.00)$ & $(0.00)$ \\
\hline & {$[0.00]$} & {$[0.46]$} & [1.51] & {$[-0.85]$} & {$[-0.92]$} & {$[-1.00]$} & {$[-1.00]$} & {$[0.00]$} & {$[0.00]$} \\
\hline \multirow[t]{4}{*}{ FS } & 0.53 & 3.34 & 0.72 & 0.05 & 0.12 & 0.03 & 0.03 & 4.81 & 1.47 \\
\hline & 0.33 & 3.34 & 0.40 & 0.34 & 0.33 & 0.05 & 0.03 & 4.81 & 1.47 \\
\hline & $(0.20)$ & $(0.00)$ & $(0.32)$ & $(-0.30)$ & $(-0.20)$ & $(-0.02)$ & $(0.00)$ & $(0.00)$ & $(0.00)$ \\
\hline & {$[0.61]$} & {$[0.00]$} & {$[0.79]$} & {$[-0.87]$} & {$[-0.63]$} & {$[-0.41]$} & {$[0.10]$} & {$[0.00]$} & {$[0.00]$} \\
\hline \multirow[t]{4}{*}{ FGR } & 5.04 & 2.72 & 22.00 & 0.09 & 0.30 & 0.21 & 0.09 & 30.45 & 8.45 \\
\hline & 2.31 & 0.88 & 22.00 & 2.41 & 2.30 & 0.36 & 0.19 & 30.45 & 8.45 \\
\hline & $(2.73)$ & $(1.84)$ & $(0.00)$ & $(-2.31)$ & $(-2.00)$ & $(-0.15)$ & $(-0.10)$ & $(0.00)$ & $(0.00)$ \\
\hline & [1.18] & {$[2.08]$} & {$[0.00]$} & {$[-0.96]$} & {$[-0.87]$} & {$[-0.42]$} & {$[-0.53]$} & {$[0.00]$} & {$[0.00]$} \\
\hline \multirow[t]{4}{*}{ AA } & 1.92 & 0.60 & 0.26 & 4.15 & 0.51 & 0.09 & 0.17 & 7.70 & 3.55 \\
\hline & 0.92 & 0.35 & 1.14 & 4.15 & 0.92 & 0.14 & 0.08 & 7.70 & 3.55 \\
\hline & $(1.00)$ & $(0.25)$ & $(-0.88)$ & $(0.00)$ & $(-0.41)$ & $(-0.05)$ & $(0.09)$ & $(0.00)$ & $(0.00)$ \\
\hline & [1.09] & {$[0.70]$} & {$[-0.78]$} & {$[0.00]$} & {$[-0.44]$} & {$[-0.38]$} & [1.14] & {$[0.00]$} & {$[0.00]$} \\
\hline \multirow[t]{4}{*}{ AG } & 2.69 & 0.84 & 0.45 & 16.91 & 19.35 & 2.50 & 0.56 & 43.30 & 23.95 \\
\hline & 6.14 & 2.36 & 7.58 & 6.40 & 19.35 & 0.96 & 0.52 & 43.30 & 23.95 \\
\hline & $(-3.45)$ & $(-1.51)$ & $(-7.13)$ & (10.51) & $(0.00)$ & $(1.53)$ & $(0.04)$ & $(0.00)$ & $(0.00)$ \\
\hline & {$[-0.56]$} & {$[-0.64]$} & {$[-0.94]$} & [1.64] & {$[0.00]$} & [1.59] & [0.08] & {$[0.00]$} & {$[0.00]$} \\
\hline \multirow[t]{4}{*}{$\mathbf{U}$} & 0.00 & 0.00 & 0.00 & 0.00 & 0.00 & 0.35 & 0.00 & 0.35 & 0.00 \\
\hline & 0.00 & 0.00 & 0.00 & 0.00 & 0.00 & 0.35 & 0.00 & 0.35 & 0.00 \\
\hline & $(0.00)$ & $(0.00)$ & $(0.00)$ & $(0.00)$ & $(0.00)$ & $(0.00)$ & $(0.00)$ & $(0.00)$ & $(0.00)$ \\
\hline & {$[-]$} & {$[-]$} & {$[-]$} & {$[-]$} & {$[-]$} & 0.00 & {$[-]$} & {$[0.00]$} & {$[-]$} \\
\hline \multirow[t]{4}{*}{$\mathbf{O}$} & 0.03 & 0.02 & 0.03 & 0.00 & 0.02 & 0.03 & 0.87 & 0.99 & 0.12 \\
\hline & 0.02 & 0.01 & 0.03 & 0.03 & 0.02 & 0.00 & 0.87 & 0.99 & 0.12 \\
\hline & $(0.01)$ & $(0.01)$ & $(0.00)$ & $(-0.03)$ & $(-0.01)$ & $(0.03)$ & $(0.00)$ & $(0.00)$ & $(0.00)$ \\
\hline & {$[0.20]$} & {$[0.57]$} & {$[-0.02]$} & {$[-1.00]$} & {$[-0.40]$} & {$[6.67]$} & {$[0.00]$} & {$[0.00]$} & {$[0.00]$} \\
\hline \multirow[t]{4}{*}{2007} & 20.42 & 7.83 & 25.20 & 21.29 & 20.34 & 3.20 & 1.71 & 100.00 & 39.74 \\
\hline & 19.93 & 7.16 & 31.84 & 13.91 & 23.48 & 1.96 & 1.73 & 100.00 & 39.74 \\
\hline & $(0.49)$ & $(0.68)$ & $(-6.64)$ & (7.38) & $(-3.13)$ & $(1.24)$ & $(-0.02)$ & $(0.00)$ & $(0.00)$ \\
\hline & {$[0.02]$} & {$[0.09]$} & {$[-0.21]$} & {$[0.53]$} & {$[-0.13]$} & {$[0.64]$} & {$[-0.01]$} & {$[0.00]$} & {$[0.00]$} \\
\hline \multirow[t]{4}{*}{ Gain } & 10.21 & 4.50 & 3.20 & 17.14 & 0.99 & 2.86 & 0.84 & 39.74 & \\
\hline & 9.72 & 3.82 & 9.84 & 9.76 & 4.13 & 1.61 & 0.86 & 39.74 & \\
\hline & $(0.49)$ & $(0.68)$ & $(-6.64)$ & (7.38) & $(-3.13)$ & $(1.24)$ & $(-0.02)$ & $(0.00)$ & \\
\hline & {$[0.05]$} & {$[0.18]$} & {$[-0.67]$} & {$[0.76]$} & {$[-0.76]$} & {$[0.77]$} & {$[-0.02]$} & {$[0.00]$} & \\
\hline
\end{tabular}




\section{Discussion}

The results obtained are based on a sampling error that remained below $5 \%$ for the estimation of the land-use and land-cover (LULC) types. This moderate error validates the methodology used for the case study at a regional scale, both in terms of the sampling effort $(1 \%)$ and the distribution of the plots, according to diverse studies (Casals et al., 2005; Di Fazio et al., 2011; Vallejo, 2018, 2005; Villanueva, 2005) and to Ambrosio and Alonso (1993), who indicated that systematic distribution is optimal to sample a vast area without previous stratification.

These results show the territorial relevance of agricultural uses and grasslands in the 1950s, in accordance with the historical importance of Mediterranean agriculture (Garrabou, 2006) and the strong weight of extensive livestock in the study area, as well as its influence in shaping the general Mediterranean landscape over centuries (Royo, 2011; Soriano, 2003). The constant agricultural and livestock abandonment during the second part of the 20th century (Collantes, 2007) can also be observed in the results. This significant trend leads to a very important increase in forest growth, both external, over abandoned agricultural uses, and internal, through densification of forest covers (Casals et al., 2005; Cervera et al., 2015; Villanueva, 2005).

Interchanges between agricultural land uses and forests are detectable in photointerpretation by the rapid appearance of a transitional cover (AA) when the crop is abandoned, or otherwise, by a new agricultural use when it is settled. Instead, the effects of the decrease in extensive livestock activity on forest vegetation are indirectly observed by the densification of forests and the loss of deforested spaces (internal forest evolution), since there is not any identifiable transition cover in the comparison between the figures of 1957 and 2007.

Systematic trends demonstrate the strength of external forest growth, contrasting with systematic resistances in the opposite direction. This systematic forest colonisation is made exclusively by woodlands and shrublands over abandoned former agricultural crops, similarly with other authors (Lasanta and Vicente-Serrano, 2007; Rindfuss et al., 2004). In parallel, the lack of capacity of the grasslands for external forest expansion or to occupy new nonforest spaces is evidenced in the obtained results. There is also no systematic trend to replace former existing forests with any other non-forest land use, but rather there is a systematic resistance to the replacement of woodlands and grasslands by any other non-forest land use. This indicates the irreversibility of external forest growth during the analysed 50 years, without any contrary systematic trend.

In the internal forest evolution, the general growth has also been made by woodlands and shrublands, over grasslands, accordingly with the general progressive trend of internal densification observed. But there is also a systematic regressive trend in the opposite direction. This regressive forest evolution in the period would have been caused mainly by wildfires, which represent in the case study area episodic but very intense disturbances causing regressive paths (Vázquez and Rodriguez-Martin, 2008; Vélez, 2000).

Regarding the paths of forest evolution, shrublands and woodlands follow different pathways, colonising separately grasslands and former agricultural crops, without being consecutive. There is neither representative nor systematic relationships between shrublands and woodlands in any regressive or progressive path and their exchanges are insignificant in both absolute and relative terms. This lack of relationship between shrublands and woodlands can be explained in various ways. Attending to the different spatial distribution patterns of both forest types (Figure 7), the remoteness of the seeds or the different environmental conditions, closely related to geographical factors (Costa, 1987), according to the different species distribution preferences (Guisan and Thuiller, 2005), could be the main reason to explain it in some cases. Other authors focus on the competitive relationships for the space occupation between species (Pearman et al., 2008) or the natural regeneration niche (Marañón et al., 2004). In any case, it means a double path for progressive and regressive forest evolution, both external and internal, that contradicts the theory of linear ecological succession regarding the facilitation stages between shrublands and woodlands (McIntosh, 1986), specifically cited in the Mediterranean basin at a scale of forest formation (RivasMartínez et al., 2011a; Siles et al., 2008; Zamora et al., 2008).

Despite the general increase of both shrublands and woodlands, the high persistence of the two main losing covers in internal and external forest evolution ( $72 \%$ of grasslands and rocky outcrops and $54 \%$ of abandoned agricultural crops), shows that forest evolution is a slow process (Lasanta and Vicente-Serrano, 2007; Molinillo et al., 1997) 
and its detailed study requires a broad time scale like we could perform in this research. The reasons for this slowness can be diverse.

In the case of abandoned agricultural crops some authors point out the remoteness of the forest seeds as the main reason (Rey et al, 2008) and some other authors highlight the need for an edaphic maturation process due to the low soil fertility for forest covers after agricultural abandonment (Lasanta and Vicente-Serrano, 2007).

Regarding grasslands and rocky outcrops, we must take into account the disturbances that have favoured this land cover, such as the wildfires in the period of study, but mainly the extensive secular grazing carried out intensely between the 15th and 20th centuries in the case study area (Royo, 2011; Soriano, 2003). This caused a total removal of woody vegetation (Molinillo et al, 1997), generating a cultural landscape with a deep soil degradation due to the continuous trampling of cattle (Sánchez et al., 2000). Consequently, this land cover (FGR) includes many areas with modest potential for forest evolution, often affected by heavy erosion processes when are placed on steep slopes and on materials vulnerable to this phenomenon (Rubio, 1989).

As indicated in the Introduction, some authors clearly distinguish the processes of change among LULC types in those depending on socioeconomic and environmental processes (Bakker and Veldkamp, 2008; Rindfuss et al. 2004; Serra et al., 2014), although they have evident relationships with each other (Corbelle-Rico et al., 2012; VidalMacua et al., 2018). In this sense, land abandonment of a plot is a change that depends on socioeconomic factors (that implies the stopping of the crop) resulting in AA, whose forest evolution (that can result in the predominance of a forest cover in the plot), is dependent on ecological factors.

The major persistence of AA in respect of the agricultural uses (54\% versus $45 \%$ ) confirms that processes of change between LULC types depending on ecological factors work, in general, on larger spatial and temporal scales (Levin, 1992) in comparison with those based on socioeconomic factors.

Notwithstanding the general slowness in forest evolution, some differences in the evolution speed are observed. Although there was a systematic resistance to direct transition from agricultural uses to forests, in external forest evolution we can observe a larger surface dominated by agricultural use in 1957 that changed directly to forests in 2007 (530 ha, 9\% of plots categorised as agricultural land in 1957), without being captured by the transition cover in any of the images, in relation to those that changed from already abandoned crops in 1957 (370 ha, 36\% of plots categorised as abandoned crops in 1957). This apparent paradox shows, on the one hand, the importance of taking into account the initial and final quantities of each category in the analysis of systematic change trends. On the other hand, it also shows that the forest evolution speed can change according to the environmental conditions of each plot since the time of abandonment may not fully explain the secondary forest succession processes and, in some cases, it may not be even its main explanatory factor (Peña-Angulo et al., 2019).

According to many authors, climate has become more unpredictable and extreme (Alpert et al., 2002; Giorgi and Lionello, 2008; Tramblay and Somot, 2018) in the Mediterranean basin, where the drought is the main limiting factor for vegetation. However, the way how this new climate condition will affect forest evolution is a matter of discussion. Some authors affirm that intensification of drought conditions in the southern Mediterranean basin in the last decades of the 20th century increased tree stand mortality for Pinus halepensis and other forest species and this phenomenon will increase in the future (Sarris et al, 2011). On the contrary, some studies assert that climate change has less influence than forest evolution for lack of management on the production of these Mediterranean forests and could even have a positive effect on their net primary productivity (Simioni et al., 2020). The resistance of Mediterranean forests to drought must be taken into account since in the most extreme situations, forests dominated by Pinus halepensis have been able to stop the desertification process (Choury et al., 2017). The evolution of forests dominated by Pinus halepensis in the study period in Castelló have presented the trend to expand especially towards the available dryer areas (Delgado-Artés, 2015).

Deep knowledge of the Mediterranean forest evolution is essential for its future sustainable management, planning the use of resources and preventing the risks related to the vicious circle formed by the abandonment of agroforestry management and climate change (Guadilla-Sáez et al., 2019; Van Leeuwen et al., 2019). Regarding this, the disturbance regime should also be taken into account for any forecast on forest evolution. In a current context of lack of agricultural and livestock pressure in large areas of the Mediterranean basin, the regressive forest 
evolution is mainly caused by wildfires, but also by pests and windthroughs (Castellnou et al., 2007; RubioCuadrado et al., 2021). However, these natural disturbances have not been capable enough to counteract the expansion and growth of the Mediterranean forest in the study area and period, but only to slow down its general increase.

Nevertheless, the fact of acquiring progressively more forest area due to these processes of forest evolution should not be considered as an advantage in an exclusive way (Otero et al., 2013). The farming abandonment that leads to this increase of forests also entails a general abandonment of forest management. The extension of continuous vast forests that accumulate more and more biomass exposed to fire, the loss of the agroforestry cultural mosaic in the territory, and the extreme conditions of drought and high temperatures derived from climate change make the risk of large wildfires grow worryingly for the Mediterranean forests (Cervera et al., 2019), with the consequent risk for human lives, ecosystems, biodiversity, infrastructures and livelihoods in Mediterranean rural areas.

Some authors consider the consequences of the rural abandonment of the second part of the 20th century as the greatest historically known transformation in the Spanish rural landscape, since human management has disappeared from wide spaces in a process of rupture of the traditional management and social structures maintained for centuries (Bauer, 2003; Gil et al, 2007; Moreno, 2007; Royo, 2011; Sevilla, 2008). In fact, forest policy in Spain, as in many other Mediterranean countries, has shifted from a primary socioeconomic perspective, providing rural employment and ensuring the supply of wood, to an environmental one since the mid-1980s, in unresolved tensions between both approaches (Rojas-Briales et al., 2018).

Additionally to its environmental effects, this landscape transformation involves many other different and complex effects to deal with (Weissteiner et al., 2011). From a spatial perspective, a new paradigm has emerged, where the former dominant agricultural uses have been and continue being replaced by forest covers in the rural areas. Besides, processes of land-use intensification linked to human activities are being developed in urban and coastal areas, deepening in the rural-urban dichotomy in Spain, with many undesirable consequences (Serra et al., 2014).

In the face of this new territorial paradigm, new and cross-cutting responses are needed, and important benefits can be obtained from them (Renwick et al., 2013). Land abandonment concerns policymakers due to its negative social, economic and environmental effects (Moravec and Zemeckis, 2007), requiring an integrated approach to rural development aligned with the specific context within each area, with special emphasis on addressing the deep territorial imbalances in facilities and infrastructures between the interior and the coast in this region (Lacruz et al., 2020; Vera, 1994). Political mitigation measures can be optimised when decision-makers know the kind and intensity of the changes affecting the specific areas (Weissteiner et al, 2011), integrating traditional top-down policy with bottom-up identification of the most urgent problems and the most feasible solutions ( $\underline{\text { ann Leeuwen et al., }}$ 2019).

In the specific case of Spain, the polarization of the current population in small coastal strips and few urban centres in non-coastal areas (e.g. Madrid) has been especially intensive and has provoked a broad recent social debate in which changes in land uses described in this article and the future mission of the new forest land is one of a long list of items. In fact, a great overlap exists between forest land and the most depopulated areas (Rojas-Briales et al., 2018).

In a predominantly urban society, shocking images of large forest fires have sparked fear of forest loss, as icons of lost nature. The political reaction has been, on the one hand, a disproportionate attention to fire suppression and on the other hand, the increasing of formal protected areas (Rojas Briales, 2019). The erroneous response given to the fires is symptomatic of a totally disconnected new narrative about forests from their origin and the recent evolution to their risks, while the overprotection of the territory limits future opportunities for the few who still maintain primary activities in those areas (Galiana et al., 2013; Pau Costa Fundation, 2016).

Under these circumstances, it is necessary to highlight the need to ensure broad, effective and sustainable forestry management practices of Mediterranean forests, tackling current risks and unlocking their benefits (Verkerk et al., 2018). Sustainable forest management comprises of multiple cross-cutting effects in the structuring of rural societies and their economies, being considered essential in responding to new challenges in the context of climate 
change, such as the bioeconomy and the enhancement of the vast potential of environmental services of the Mediterranean forests (EFI, 2009; Falcone et al., 2020; Varela et al., 2020).

\section{Conclusions}

The use of $1 \%$ photointerpretation sampling and multi-temporal analysis techniques has allowed us to study the evolution trends of land-use and land-cover types on a wide spatial and temporal scale under Mediterranean conditions, specifically in the province of Castelló (Valencian Region, Spain) during the most intensive known land abandonment phase (1957-2007). Applying this methodology, two processes have shown to be important in the territory: (i) agricultural abandonment, and (ii) forest expansion as a consequence of it. Furthermore, these processes have proven to be strong, systematic and irreversible under the conditions described.

At the scale of forest formations, the relative strength of the evolution paths has been assessed, as well as the resistances between them, which made it possible to draw a map of forest evolution. A double path of forest evolution has been evidenced, external and internal, progressive and regressive. No systematic relationships between shrublands and woodlands were found in any direction, and their exchanges were negligible both in absolute and relative terms, in contrast to some existing theories about linear forest succession under Mediterranean conditions, referring to facilitation stages between shrubs and trees.

In this evolution process, the external increase of forests showed a strong and systematic trend, with a clear systematic resistance to reversibility, consisting of the colonisation of agricultural abandoned spaces by shrubs and especially trees, according to the aforementioned double path. Due to the difference in velocity between the two processes, i.e., land abandonment and forest colonisation and evolution, there is a large stock of spaces dominated by the transitional cover of agricultural abandoned lands. Owing to this, it is foreseeable that in the absence of a change in the current socioeconomic cycle, which is unlikely according to different authors, the external increase of forests will continue in the future.

The internal forest evolution showed a strong systematic trend to densification, according to the previously established alternative double path. However, differently than external evolution, this double path was not unidirectional, but also reversible. Systematic regressive trends of evolution were identified, but they were weaker than progressive ones. The reversibility of forest densification is mainly due to the largest disturbance agents of the forest covers, i.e., wildfires.

The speed of the forest evolution processes described could be discussed depending on the scale and the particularities of each area. In fact, in this case study, different evolution speeds of the forest types have also been identified, which may depend on site conditions, whose specific soil and climatic factors should be further studied at a local scale. The clear trend of the general progressive evolution of the forests that has been measured is the result of the large temporal and spatial scale applied, beyond local singularities. This scale incorporates the management, disturbances and climatic circumstances of a long study period, where socioeconomic changes -rural abandonment- have been the most important, beyond environmental changes.

Future predictions on both the external and internal evolution of forests, will have to take into account socioeconomic and environmental scenarios. On the one hand, socioeconomic context is not foreseeable to change in the sense of recovery of agricultural uses and therefore, unidirectional external forest increase is expected to continue over agricultural abandoned covers. On the other hand, future balance and velocity in the -bidirectionalinternal forest evolution will depend on the future evolution of the disturbance regime, which will be conditioned by environmental changes.

Beyond forecasting the future, the described process and its consequences has already brought a new paradigm, where human uses are no longer those that structure the territory but rather the forest covers. A dramatic change in landscape use is about to culminate after 150 years in which most areas of the northern Mediterranean have moved from a predominantly primary economy based on agriculture and pastoralism, to a concentrated and urbanized society characterized by a marginal primary sector. This supposes a hitherto unknown territorial predominance of forest cover without a clear mission or use and increasingly threatened by forest fires. Unique 
exceptions are found on the coastal edge and the narrow plains existing there, with optimal conditions for intensive agriculture, although they are highly affected by urban uses.

This new situation has multiple, complex and important economic, social and environmental consequences and challenges, which should be faced urgently in an integrated manner, including the cross-cutting risks that derive from it, while managing spatial resources, especially the forest ones, in a sustainable way.

Eventually, the emerging debate could place forestry policy as a pillar of spatial cohesion not only in this part of the world but in many others. However, as recognized in many international forums during the past decade (FAO, 2014), capturing the contribution of forests to rural livelihoods has been very elusive without reliable and comparable information. Research-based statistics capable of showing the importance of the forestry value chain, including informal activities in spatial terms, are crucial. Understanding the driving role of forestry as well as its contribution to social resilience in sparsely populated areas is vital for future policy. Finally, different forest management scenarios and their spatial effects on livelihoods or risks such as forest fires and their results on carbon stocks and watershed services, can illustrate future policies tailored to sparsely populated areas.

\section{CRediT authorship contribution statement}

Rafael Delgado-Artés: Conceptualization, Methodology, Formal analysis, Investigation, Writing - original draft, Writing - review \& editing, Visualization, Project administration. Virginia Garófano-Gómez: Methodology, Formal analysis, Investigation, Resources, Writing - original draft, Writing - review \& editing, Visualization. JoséVicente Oliver-Villanueva: Methodology, Writing - review \& editing. Eduardo Rojas-Briales: Conceptualization, Methodology, Writing - review \& editing, Funding acquisition.

\section{Declaration of Competing Interest}

The authors declare that they have no known competing financial interests or personal relationships that could have appeared to influence the work reported in this paper.

\section{Acknowledgements}

We thank Ana Alonso Panadero for her help in data acquisition and the help of the Spanish Ministry of Agriculture and Environment through the research project entitled "Interpretation of the incident factors in the intensity of spontaneous recovery of forest formations in the Mediterranean basin through the comparison of aerial photographs, implementation of historical environmental information and geostatistical techniques". We thank the reviewers for their valuable comments.

\section{References}

Alamá-Sabater, L., Budí, V., Roig-Tierno, N., García-Álvarez-Coque, J.M., 2021. Drivers of depopulation and spatial interdependence in a regional context. Cities 114, 103217. https://doi.org/10.1016/j.cities.2021.103217.

Allaire, J.J., Gandrud, C., Russell, K., Yetman, C., 2017. networkD3: D3 JavaScript Network Graphs from R. R package version 0.4 .

Allué, J.L., 1990. Atlas Fitoclimático de España: Taxonomías. INIA, Madrid. 
Alo, C.A., Pontius, R.G., 2008. Identifying Systematic Land-Cover Transitions Using Remote Sensing and GIS: The Fate of Forests inside and outside Protected Areas of Southwestern Ghana. Environ. Plan. B Plan. Des. 35, 280-295. https://doi.org/10.1068/b32091.

Alpert, P., Ben-Gai, T., Baharad, A., Benjamini, Y., Yekutieli, D., Colacino, M., Diodato, L., Ramis, C., Homar, V., Romero, R., 2002. The paradoxical increase of Mediterranean extreme daily rainfall in spite of decrease in total values. Geophys. Res. Lett. 29, 31.

Alrababah, M.A., Alhamad, M.N., 2006. Land use/cover classification of arid and semi-arid Mediterranean landscapes using Landsat ETM. Int. J. Remote Sens. 27, 2703-2718. https://doi.org/10.1080/01431160500522700.

Ambrosio, L., Alonso, R., 1993. Estimación de superficies cultivadas por muestreo de áreas y teledetección. Precisión relativa. Estad. Esp. 35, 91-103.

Anderson, J.R., Hardy, E.E., Roach, J.T., Witmer, R.E., 1976. A land use and land cover classification system for use with remote sensor data, U.S Geological Survey Professional Paper. Whasington, D.C.

Arnaez, J., Lasanta, T., Errea, M.P., Ortigosa, L., 2011. Land abandonment, landscape evolution, and soil erosion in a Spanish Mediterranean mountain region: the case of Camero Viejo. L. Degrad. Dev. 22, 537-550. https://doi.org/10.1002/ldr.1032.

Arnáez, J., Oserin, M., Ortigosa, L., Lasanta, T., 2008. Cambios en la cubierta vegetal y usos del suelo en el sistema ibérico noroccidental entre 1956 y 2001: Los Cameros (La Rioja, España). Bol. Asoc. Geogr. Esp. 195-212.

Arranz, E.R., 1980. La transición demográfica en España. Rev. Esp. Investig. Socio._233-240.

Badal, E., 2017. Bosques, campos y pastos: el potencial económico de la vegetación mediterránea. SAGVNTVM Extra 5, 129-146.

Bakker, M.M., Veldkamp, A., 2008. Modelling land change: the issue of use and cover in wide-scale applications. J. Land Use Sci. 3, 203-213. https://doi.org/10.1080/17474230802465181.

Bauer, E., 2003. Los Montes de España en la Historia, 3 edición. ed. Fundación Conde del Valle de Salazar, Madrid.

Bivand, R.S., Pebesma, E., Gómez-Rubio, V., 2013. Spatial data import and export. In:_Applied Spatial Data Analysis with R. Springer, New York, pp. 83-125.

Blondel, J., 2006. The "design" of Mediterranean landscapes: a millennial story of humans and ecological systems during the historic period. Hum. Ecol. 34, 713-729. https://doi.org/10.1007/s10745-006-9030-4.

Bossard, M., Feranec, J., Otahel, J., 2000. CORINE Land Cover Technical Guide: Addendum 2000. European Environment Agency, Copenhagen, Copenhagen.

Braimoh, A.K., 2006. Random and systematic land-cover transitions in northern Ghana. Agric. Ecosyst. Environ. 113, 254-263. https:// doi.org/10.1016/j.agee.2005.10.019.

Brunsdon, C., Chen, H., 2014. GISTools: Some further GIS capabilities for R. R Packag. version 0.7-2.

Buhk, C., Götzenberger, L., Wesche, K., Gómez, P.S., Hensen, I., 2006. Post-fire regeneration in a Mediterranean pine forest with historically low fire frequency. Acta Oecologica 30, 288-298. https://doi.org/10.1016/j.actao.2006.05.010.

Büttner, G., Feranec, J., Jaffrain, G., Mari, L., Maucha, G., Soukup, T., 2004. The CORINE land cover 2000 project. EARSeL eProceedings 3, 331-346. 
Camarero, L., 1991. Tendencias recientes y evolución de la población rural en España. Polít. Soc. 13-24.

Camarero, L., Cruz, F., González, M., del Pino, J.A., Oliva, J., Sampedro, R., 2009. The rural population in Spain, Barcelona: La Caixa. Barcelona.

Casals, V., Pardo, F., Xalabarder, M., Postigo, J.M., Gil, L., 2005. La transformación histórica del paisaje forestal en Cataluña, Madrid, Tercer Inventario Forestal Nacional, Ministerio de Medio Ambiente.

Castellnou, M., Nebot, E., Miralles, M., 2007. El papel del fuego en la gestión del paisaje, in: 4th International Wildland Fire Conference. Sevilla, pp. 13-17.

Castellnou, M., Miralles, M., Piqué, M., 2009. Tipificación de los incendios forestales de Cataluña. Elaboración del mapa de incendios de diseño como herramienta para la gestión forestal, in: Congreso Forestal Español. SECF. Junta de Castilla y León, Ávila, p. 16.

Cervera, T., Garrabou, R., Tello, E., 2015. Política forestal y evolución de los bosques en Cataluña desde el siglo XIX hasta la actualidad. Investig. Hist. Econ. 11, 116-127. https://doi.org/10.1016/j.ihe.2014.04.002.

Cervera, T., Pino, J., Marull, J., Padró, R., Tello, E., 2019. Understanding the long-term dynamics of forest transition: From deforestation to afforestation in a Mediterranean landscape (Catalonia, 1868-2005). Land Use Policy 80, 318-331. https://doi.org/10.1016/j.landusepol.2016.10.006.

Choury, Z., Shestakova, T.A., Himrane, H., Touchan, R., Kherchouche, D., Camarero, J.J., Voltas, J., 2017. Quarantining the Sahara desert: growth and water-use efficiency of Aleppo pine in the Algerian Green Barrier. Eur. J. For. Res. 136, 139-152. https://doi.org/10.1007/s10342-016-1014-3.

CITMA, 2012. Plan de Acción Territorial Forestal de la Comunitat Valenciana. València.

Collantes, F., 2001. El declive demográfico de la montaña española, 1860-1991: revisión crítica de propuestas teóricas.

Collantes, F., 2007. La desagrarización de la sociedad rural española, 1950-1991. Hist._Agrar. SEHA 42, 251-276.

Corbelle-Rico, E., Crecente-Maseda, R., Santé-Riveira, I., 2012. Multi-scale assessment and spatial modelling of agricultural land abandonment in a European peripheral region: Galicia (Spain), 1956-2004. Land Use Policy 29, 493-501. https://doi.org/10.1016/j.landusepol.2011.08.008.

Costa, M., 1987. La vegetació al País Valencià. Universitat de València.

Delgado-Artés, R., 2015. Análisis de los patrones de evolución de las coberturas forestales en la provincia de Castellón en los últimos 50 años. Universitat Politècnica de València.

Di Fazio, S., Modica, G., Zoccali, P., 2011. Evolution Trends of Land Use/Land Cover in a Mediterranean Forest Landscape in Italy, in: Murgante B., Gervasi O., Iglesias A., Taniar D., A.B.O. (Ed.), International Conference on Computational Science and Its Applications. Springer, Berlin, Heidelberg, Springer, Berlin, Heidelberg, pp. 284 299. https://doi.org/10.1007/978-3-642-21928-3_20.

EFI, 2009. Plan Stratégique de Recherche sur les Forêts méditerranéennes 2010-2020. European Forest Institute, UNESCO-FAO, Forest-Based Sector Technology Platform, Barcelona.

Estrada-Villegas, S., DeMalach, N., Martinez Ramos, M., Ladwig, L.M., Meiners, S.J., Werden, L.K., Schnitzer, S.A., 2020. Review of the symposium determinism and stochasticity in ecological succession in ESA-Louisville, 2019. Bull. Ecol. Soc. Am. 101, 1-6. https://doi.org/10.1002/bes2.1687.

Falcone, P.M., Tani, A., Tartiu, V.E., Imbriani, C., 2020. Towards a sustainable forest- based bioeconomy in Italy: findings from a SWOT analysis. For. Policy Econ. 110, 101910 https://doi.org/10.1016/j.forpol.2019.04.014. 
FAO, 2014. State of the World's Forests. Roma.

Ferran, A., Baeza, J., Bautista, S., Caturla, R.N., Llovet, J., 2003. La regeneració natural després dels incendis forestals a la Comunitat Valenciana.

Ferriol, M., López, C., 2016. La sucesión vegetal, Objetos de aprendizaje UPV. Universitat Politècnica de València, València (España).

Fisher, P.F., Comber, A.J., Wadsworth, R., 2005. Land use and Land cover: contradiction or Complement. In: Fisher, P., Unwind, D.J. (Eds.), Re-Presenting GIS. John Wiley \& Sons Ltd., Chichester, West Sussex, England, pp. $85-98$.

Franco, C., Revert, A., Mediavilla, J., Núñez, J.Á., 2019. Análisis estadístico de incendios forestales en la Comunitat Valenciana y modificación del índice de peligrosidad de incendios (PIF), in: Sexto Simposio Nacional de Predicción “Memorial Antonio Mestre." Agencia Estatal de Meteorología, pp. 697-708. https://doi.org/10.31978/639-19010-0.697.

Galiana, L., Aguilar, S., Lázaro, A., 2013. An assessment of the effects of forest-related policies upon wildland fires in the European Union. For. Policy Econ. 29, 36-44. https://doi.org/10.1016/j.forpol.2012.10.010.

Gámir, A., Méndez, R., Molinero, T., Razquín, J., 1989. Terciarización económica y_desarrollo regional en España. Geogr. Univ. Complut. 123-144.

Garavaglia, V., Besacier, C., 2014. El estado de los bosques mediterráneos en 2013. Unasylva 65, 3-14.

García, J.M., Lasanta, T., 2018. El Pirineo Aragonés como paisaje cultural. Pirin. Rev._Ecol. Mont. 173, 62-105.

García-Romero, A., Muñoz, J., Andrés, N., Palacios, D., 2010. Relationship between climate change and vegetation distribution in the Mediterranean mountains: Manzanares Head valley, Sierra De Guadarrama (Central Spain). Clim. Change 100, 645-666. https://doi.org/10.1007/s10584-009-9727-7.

Garrabou, R., 2006. Historia agraria dels Països Catalans, IV: SEGLES XIX-XX. Barcelona. Gil, L., de Castilla, J., Leon, V.S., de Fomento, C., Anton, T., Picardo Nieto, A., 2007. Atlas forestal de Castilla y León. Valladolid (Spain) Junta de Castilla y Leon, Consejeria de Fomento y Medio ....

Giorgi, F., Lionello, P., 2008. Climate change projections for the Mediterranean region._Glob. Planet. Change 63, 90-104.

Guadilla-Sáez, S., Pardo-de-Santayana, M., Reyes-García, V., 2019. The role of traditional management practices in shaping a diverse habitat mosaic in a mountain region of Northern Spain. Land Use Policy 89, 104235. https://doi.org/10.1016/j.landusepol.2019.104235.

Guisan, A., Thuiller, W., 2005. Predicting species distribution: offering more than simple habitat models. Ecol. Lett. 8, 993-1009. https://doi.org/10.1111/j.1461-0248.2005.00792.x.

Heredia-Laclaustra, A., Frutos-Mejías, L.M., González Hidalgo, J.C., 2013. Diferencias en la evolución del paisaje entre dos municipios prepirenaicos (Alquézar y Valle de Lierp) durante la segunda mitad del siglo XX 168, $77-$ 101. https://doi.org/10.3989/Pirineos.2013.168005.

ICV, 2001. Mapa topográfico escala 1:25.000.

Kosztra, B., Büttner, G., Hazeu, G., Arnold, S., 2017. Updated CLC illustrated nomenclature guidelines. Eur. Environ. Agency Wien., Austria 1-124.

Lacruz, J.L., Terrado, P.R., Olivares, P.A., 2020. Educación y vertebración del territorio: un estudio de caso en torno a la escuela rural de Teruel. Temps d'Educació 27-46. 
Lasanta, T., Vicente-Serrano, S.M., 2007. Cambios en la cubierta vegetal en el Pirineo aragonés en los últimos 50 años. Pirineos 162,125-154. https://doi.org/10.3989/pirineos.2007.v162.16.

Levin, S.A., 1992. The problem of pattern and scale in ecology: the Robert H. MacArthur Award Lecture. Ecology 73, 1943-1967. https://doi.org/10.2307/1941447.

Lindner, M., Maroschek, M., Netherer, S., Kremer, A., Barbati, A., Garcia-Gonzalo, J., Seidl, R., Delzon, S., Corona, P., Kolström, M., Lexer, M., Marchetti, M., 2010. Climate change impacts, adaptive capacity, and vulnerability of European forest ecosystems. For. Ecol. Manag. 259, 698-709. https://doi.org/10.1016/j.foreco.2009.09.023.

Lizárraga, C., Chica-Olmo, C., 2014. Crecimiento económico y cortes estructurales. El caso de Andalucía (19001999)*. Trimest. Econ. LXXXI, 199-225.

Magalhaes, L., 2009. Evolución climático-hidrológica reciente y cambios en los usos del suelo en diversas cuencas de cabecera de los ríos Duero y Tajo. Universidad de Salamanca.

Marañón, T., Camarero, J.J., Castro Gutiérrez, J., Díaz Esteban, M., Espelta, J.M.,_Hampe, A., Jordano, P., Valladares Ros, F., Verdú, M., 2004. Heterogeneidad ambiental y nicho de regeneración. Ecotropicos 10 (2), 133150.

Margalef, R., 1993. Teoría de los sistemas ecológicos. Edicions Universitat Barcelona, Barcelona.

Martín, M.P., Chuvieco, E., Aguado, I., 1998. La incidencia de los incendios forestales en España. Ser. Geogr. 7, 23-36.

Martínez-Fernández, J., Ruiz-Benito, P., Zavala, M.A., 2015. Recent land cover changes in Spain across biogeographical regions and protection levels: Implications for conservation policies. Land Use Policy 44, 62-75. https://doi.org/10.1016/j.landusepol.2014.11.021.

Mataix-Solera, J., Cerdà, A., 2009. Incendios forestales en España. Ecosistemas terrestres y suelos. Efectos los Incend. For. sobre los suelos en España. El estado la cuestión visto por los científicos españoles. 27-53.

McIntosh, R.P., 1986. The Background of Ecology: Concept and Theory. Cambridge University Press, Cambridge, UK.

Meira, P.A., Arto, M., Heras, F., Lorenzo, J.J., Lorenzo, J.J., Montero, P., 2013. La sociedad española ante el cambio climático. Percepción y comportamientos en la población. Ideara Investigación, Madrid.

Molina, D., 2002. El proceso de desertización demográfica de la montaña pirenaica en el largo plazo: Cataluña. Ager. Rev. Estud. sobre Despoblación y Desarro. Rural 2, 81-100.

Molinillo, M., Lasanta, T., García-Ruiz, J.M., 1997. Managing mountainous degraded landscapes after farmland abandonment in the Central Spanish Pyrenees. Environ. Manag. 21, 587-598.

Moravec, J., Zemeckis, R., 2007. Cross compliance and land abandonment. A Res. Pap. Cross-Compliance Netw. (Contract Eur. Community's Sixth Framew. Program. SSPE- CT-2005-022727), Deliv. D17 Cross-Compliance Netw.

Moreno, J.M., 2007. Cambio global e incendios forestales: una visión desde España, in: 4a Conferencia Internacional Sobre Incendios Forestales. Sevilla, p. 22.

Moreno, J.M., Rosa, D., Zazo, C., 2005. Evaluación preliminar de los impactos en España por efecto del cambio climático. España. Ministerio de Medio Ambiente, Madrid. 
Muñoz-Rojas, J., Pinto-Correia, T., Napoleone, C., 2019. Farm and land system dynamics in the Mediterranean: Integrating different spatial-temporal scales and management approaches. Land Use Policy 88, 104082. https://doi.org/10.1016/j.landusepol.2019.104082.

Muñoz-Rojas, M., De la Rosa, D., Zavala, L.M., Jordán, A., Anaya-Romero, M., 2011. Changes in land cover and vegetation carbon stocks in Andalusia, Southern Spain (1956-2007). Sci. Total Environ. 409, 2796-2806. https://doi.org/10.1016/j.scitotenv.2011.04.009.

Myers, N., Mittermeier, R.A., Mittermeier, C.G., da Fonseca, G.A.B., Kent, J., 2000. Biodiversity hotspots for conservation priorities. Nature 403, 853-858. https://doi.org/10.1038/35002501.

Odum, E., Barret, G., 2006. Fundamentos de Ecología. Cengage learning, Mexico.

Olcina, J., 2009. Cambio climático y riesgos climáticos en España. Investig. Geográficas._Inst. Univ. Geogr. Univ. Alicant. 49, 197-220.

Ortega, T.M., Cobo, F., 2004. Las consecuencias de la derrota. El regreso a la agricultura tradicional y el sometimiento de la población campesina en Andalucía oriental durante la primera etapa del régimen franquista, 1939-1953. Estud. d'història agrària 281-297.

Otero, I., 2010. The rural-urban socioecological transformation of Mediterranean mountain areas under global change Local studies in Olzinelles and Matadepera (Barcelona Metropolitan Region). Universitat Autònoma de Barcelona (UAB).

Otero, I., Boada, M., Tàbara, J., 2013. Social-ecological heritage and the conservation of Mediterranean landscapes under global change. A case study in Olzinelles (Catalonia). Land Use Policy 30, 25-37. https://doi.org/10.1016/j.landusepol.2012.02.005.

Pau Costa Fundation, 2016. Decalogue of forest fires [WWW Document].

Pausas, J.G., Fernández-Muñoz, S., 2012. Fire regime changes in the Western Mediterranean Basin: from fuellimited to drought-driven fire regime. Clim. Change 110, 215-226. https://doi.org/10.1007/s10584-011-0060-6.

Pausas, J.G., Llovet, J., Rodrigo, A., Vallejo, R., 2008. Are wildfires a disaster in the Mediterranean basin? - A review. Int. J. Wildl. Fire 17, 713. https://doi.org/10.1071/WF07151.

Pearman, P.B., Guisan, A., Broennimann, O., Randin, C.F., 2008. Niche dynamics in space and time. Trends Ecol. Evol. 23, 149-158. https://doi.org/10.1016/j.tree.2007.11.005.

Peña-Angulo, D., Khorchani, M., Errea, P., Lasanta, T., Martínez-Arnáiz, M., Nadal-Romero, E., 2019. Factors explaining the diversity of land cover in abandoned fields in a Mediterranean mountain area. Catena 181. https://doi.org/10.1016/j.catena.2019.05.010.

Pickett, S., Cadenasso, M.L., Meiners, S.J., 2009. Ever since Clements: from succession to vegetation dynamics and understanding to intervention*. Appl. Veg. Sci. 12, 9-21. https://doi.org/10.1111/j.1654-109X.2009.01019.x.

Pinilla, V., Sáez, L.A., 2017. Rural depopulation in Spain: genesis of a problem and innovative policies. Zaragoza, Spain Cent. Stud. Depopulation Dev. Rural Areas.

Pontius, R.G., Shusas, E., McEachern, M., 2004. Detecting important categorical land changes while accounting for persistence. Agric. Ecosyst. Environ. 101, 251-268. https://doi.org/10.1016/j.agee.2003.09.008.

Poyatos, R., Latron, J., Llorens, P., 2003. Land use and land cover change after agricultural abandonment. Mt. Res. Dev. 23, 362-368. https://doi.org/10.1659/ 0276-4741(2003)023[0362:LUALCC]2.0.CO;2. 
Quílez, R., 2019. Los incendios forestales en la Comunitat Valenciana en el contexto del cambio climático. In: III Congreso Forestal de La CV: Gestión de incendios forestales en el contexto del cambio climático. Universitat de València, pp. 8-28.

R Development Core Team, 2014. R: A language and environment for statistical computing.

Reher, D.S., Sanz-Gimeno, A., 2007. Rethinking historical reproductive change: insights from longitudinal data for a Spanish Town. Popul. Dev. Rev. 33, 703-727. https://doi.org/10.1111/j.1728-4457.2007.00194.x.

Reid, W.V., Mooney, H.A., Cropper, A., Capistrano, D., Carpenter, S.R., Chopra, K., Dasgupta, P., Dietz, T., Duraiappah, A.K., Hassan, R., 2005. Ecosystems and Human Well-Being-Synthesis: A Report of the Millennium Ecosystem Assessment. Island Press.

Renwick, A., Jansson, T., Verburg, P.H., Revoredo-Giha, C., Britz, W., Gocht, A., McCracken, D., 2013. Policy reform and agricultural land abandonment in the EU. Land Use Policy 30, 446-457. https://doi.org/10.1016/j.landusepol.2012.04.005.

Rey, J.M., Bullock, J.M., Newton, A.C., 2008. Creación de islotes forestales para_reconciliar restauración ecológica, conservación y uso agrícola. Cuad. Soc. Esp. Cienc. 277-282.

Rifà, A., Castellnou, M., 2007. El modelo de extinción de incendios forestales catalan, in: IV Internacional Conference of Wildfire and Forest Fire Research. Sevilla, p. 11.

Rindfuss, R.R., Walsh, S.J., Turner, B.L., Fox, J., Mishra, V., 2004. Developing a science of land change: challenges and methodological issues. Proc. Natl. Acad. Sci. 101, 13976-13981. https://doi.org/10.1073/pnas.0401545101.

Rivas-Martínez, S., Peñas, A., Díaz, T., Ladero, M., Asensi, A., Díez, B., López, M.L., 2011a. Mapa de series, geoseries y geopermaseries de vegetación de España Parte II. Universidad de León, León.

Rivas-Martínez, S., Sáenz, S., Peñas, A., 2011b. Worldwide bioclimatic classification system. Glob. Geobot. 1, 634. https://doi.org/10.5616/gg110001.

Robles, E., Bernabeu-Mestre, J., Gacía, F., 1996a. La transición sanitaria: una revisión_conceptual. Rev. Demogr. Hist. 14, 117-142.

Robles, E., García, F., Bernabeu-Mestre, J., 1996b. La transición sanitaria en España desde 1900 a 1990. Rev. Esp. Salud Publica 70, 221-233.

Rojas Briales, E., 2019. Elementos para una visión de futuro de los bosques europeos._Montes 6-10.

Rojas-Briales, E., Delgado-Artés, R., Cabrera-Bonet, M., 2018. Human desertification and disempowerment of rural territories. In: Forestry in the Midst of Global Changes. CRC Press, pp. 101-134.

Royo, V., 2011. L'influence de l'élevage dans l'organisation du paysage du village de Culla (XVe-XVIIe siècles). Domitia. Rev. du Cent. Rech. Hist. les sociétés méditerranéennes 12, 123-142.

Rubio, J.L., 1989. Erosión del suelo y gestión ambiental en condiciones mediterráneas._Options Méditerranéennes (Seri séminaires) 3, 323-326.

Rubio-Cuadrado, Á., López, R., Rodríguez-Calcerrada, J., Gil, L., 2021. Stress and tree mortality in Mediterranean pine forests: anthropogenic influences. In: Pines and Their Mixed Forest Ecosystems in the Mediterranean Basin. Springer, pp. 141-181.

Sánchez, J., Añó, C., Carbó, E., Pascual, J.A., Antolín, C., Colomer, J.C., 2000._Orientaciones de uso agrario de la Comunidad Valenciana. Escala 1: 300.000. Edafología 7-3, 1-10. 
Sarkar, D., 2008. Lattice: Multivariate Data Visualization with R. Springer Science \&_Business Media, New York.

Sarris, D., Christodoulakis, D., Körner, C., 2011. Impact of recent climatic change on growth of low elevation eastern Mediterranean forest trees. Clim. Change 106, 203-223. https://doi.org/10.1007/s10584-010-9901-y.

Serra, P., Vera, A., Tulla, A.F., Salvati, L., 2014. Beyond urban-rural dichotomy: exploring socioeconomic and land-use processes of change in Spain (1991-2011). Appl. Geogr. 55, 71-81. https://doi.org/10.1016/j.apgeog.2014.09.005.

Sevilla, F., 2008. Una teoría ecológica para los montes ibéricos, Froilán Sevilla Martínez. IRMA. León. ES.

Siles, G., Rey, P.J., Alcántara, J.M., Ramírez, J.M., 2008. Assessing the long-term contribution of nurse plants to restoration of Mediterranean forests through Markovian models. J. Appl. Ecol. 45, 1790-1798. https://doi.org/10.1111/j.1365-2664.2008.01574.x.

Simioni, G., Marie, G., Davi, H., Martin-St Paul, N., Huc, R., 2020. Natural forest dynamics have more influence than climate change on the net ecosystem production of a mixed Mediterranean forest. Ecol. Modell. 416,108921 https://doi.org/10.1016/j.ecolmodel.2019.108921.

Soler, V., Marco, V.S., 2004. Economia espanyola i del País Valencià. Universitat de València.

Solsona, J., López, D., 2012. Factores de localización y desarrollo turístico en el espacio rural de la Comunitat Valenciana. Boletín la Asoc. Geógr. Esp. 59, 221-244.

Soriano, J., 2003. Aprovechamiento histórico y situación actual del bosque en Castelló. Universitat Jaume I.

Teixidó, A.L., Quintanilla, L.G., Carreño, F., Gutiérrez, D., 2010. Impacts of changes in land use and fragmentation patterns on Atlantic coastal forests in northern Spain. J. Environ. Manag. 91, 879-886. https://doi.org/10.1016/j.jenvman.2009.11.004.

Tramblay, Y., Somot, S., 2018. Future evolution of extreme precipitation in the Mediterranean. Clim. Change 151, 289-302.

Uríos, J.I., 2005. Análisis del régimen de incendios forestales en los montes de Portaceli_durante El Siglo XX (Serra, Valencia). Cuad. Geogr. Univ. València 76, 219-238.

Vadell, E., De Miguel, S., Fernández Centeno, G., Robla, E., Lerner, M., Pemán García, J., 2019. La forestación de tierras agrícolas: balance de un instrumento de política forestal para el cambio del uso de la tierra. Cuad. la Soc. Esp. Cienc. 45, 1-20. https://doi.org/10.31167/csecfv0i45.19497.

Valera, A., Añó, C., Sánchez, J., 2017. Transformación de usos agrícolas tradicionales en superficies construidas. Cambios en los usos y coberturas del suelo en el municipio de Valencia (1956-2012). Estud. Geogr. 77, 671. https://doi.org/10.3989/estgeogr.201623.

Vallecillo, S., 2009. Los cambios en el paisaje y su efecto sobre la distribución de las especies: modelización y aplicación a la conservación de las aves de hábitats abiertos en paisajes mediterráneos. Centre Tecnològic Forestal de Catalunya.

Vallejo, R., 2005. El mapa forestal de España escala 1: 50.000 (MFE50) como base del tercer inventario forestal nacional. Cuad. Soc. Esp. Cienc. 205-210.

Vallejo, R., 2018. Tercer Inventario Forestal Nacional. Ministerio de Agricultura, Alimentación y Medio Ambiente (España/Spain). Versión 1.4. Spanish Ministry of Agriculture, Food and Environ. https://doi.org/10.15468/tkezjv.

Van Laar, A., Akca, A., 2007. Forest mensuration. Dordrecht. 
Van Leeuwen, C.C.E., Cammeraat, E.L.H., de Vente, J., Boix-Fayos, C., 2019. The evolution of soil conservation policies targeting land abandonment and soil erosion in Spain: a review. Land Use Policy 83, 174-186. https://doi.org/10.1016/j.landusepol.2019.01.018.

Varela, E., Pulido, F., Moreno, G., Zavala, M.Á., 2020. Targeted policy proposals for managing spontaneous forest expansion in the Mediterranean. J. Appl. Ecol. 57, 2373-2380. https://doi.org/10.1111/1365-2664.13779.

Vázquez, A., Rodriguez-Martin, J.A., 2008. Dinámica de paisajes forestales en relación a_la incidencia del fuego en España peninsular: 1987-2000. Syst. 17, 143-154.

Vélez, R., 2000. La defensa contra incendios forestales: fundamentos y experiencias.

Vélez, R., 2018. Cambio global e incendios forestales: perspectivas en la Europa_Meridional. Recur. Rurais 49-54.

Vera, J.R. de, 1994. Modelo territorial valenciano y distribución de la red de carreteras.

Verburg, P.H., van Berkel, D.B., van Doorn, A.M., van Eupen, M., van den Heiligenberg, H.A.R.M., 2010. Trajectories of land use change in Europe: a model- based exploration of rural futures. Landsc. Ecol. 25, 217-232. https://doi.org/ 10.1007/s10980-009-9347-7.

Verkerk, P.J., De Arano, I.M., Palahí, M., 2018. The bio-economy as an opportunity to tackle wildfires in Mediterranean forest ecosystems. For. Policy Econ. 86, 1-3. https://doi.org/10.1016/j.forpol.2017.10.016.

Vidal-Macua, J.J., Ninyerola, M., Zabala, A., Domingo-Marimon, C., Gonzalez-Guerrero, O., Pons, X., 2018. Environmental and socioeconomic factors of abandonment of rainfed and irrigated crops in northeast Spain. Appl. Geogr. 90, 155-174. https://doi.org/10.1016/J.APGEOG.2017.12.005.

Villanueva, J.A. (coord), 2005. Tercer Inventario Forestal Nacional (1997-2007). ICONA. Ministerio de Medio Ambiente., Madrid.

Walker, L., 2005. Margalef y la sucesión ecológica. Ecosistemas 14, 66-78.

Weissteiner, C.J., Boschetti, M., Böttcher, K., Carrara, P., Bordogna, G., Brivio, P.A., 2011. Spatial explicit assessment of rural land abandonment in the Mediterranean area. Glob. Planet. Change 79, 20-36. https://doi.org/10.1016/j. gloplacha.2011.07.009.

Zamora, R., García-Fayos, P., Gómez, L., 2008. Las interacciones planta-planta y planta-animal en el contexto de la sucesión ecológica, in: Valladares, F. (Ed.), Ecología Del Bosque Mediterráneo En Un Mundo Cambiante. España. Ministerio de Medio Ambiente y Medio Rural y Marino, Madrid, pp. 373-396. 